\title{
Burial depth and post-Early Cretaceous uplift of Lower-Middle Jurassic strata in the Fennoscandian Border Zone based on organic maturity
}

\author{
Henrik I. Petersen, Lars H. Nielsen, Torben Bidstrup and Erik Thomsen
}

\begin{abstract}
The burial depth and the magnitude of Late Cretaceous - Early Cenozoic and Neogene-Pleistocene uplift of Lower-Middle Jurassic strata in the Fennoscandian Border Zone are estimated from measurements of huminite reflectance and comparison with a regional coalification gradient. The regional coalification curve is constructed by plotting uplift-corrected sample depths against more than 300 huminite/vitrinite reflectance values from Upper Triassic - Lower Cretaceous deposits in the Danish Basin and the Fennoscandian Border Zone. The present sample depths are corrected for Late Cretaceous inversion in the Sorgenfrei-Tornquist Zone and for Neogene-Pleistocene regional uplift. A coalification curve is erected; it cuts the abscissa at $0.2 \% \mathrm{R}_{\mathrm{o}}$ corresponding to the reflectance of peat. This curve is considered to approximate to a reliable coalification profile over much of the study area.

The Jurassic coals from the Fennoscandian Border Zone are of low rank and, based on the regional coalification curve, they have been buried to $c$. 625-2450 m. In the eastern part of the Rønne Graben, in the Kolobrzeg Graben and in the Arnager-Sose Fault Block, the Jurassic strata were subsequently uplifted c. 290-1400 m, corresponding to the amount of Late Cretaceous Early Cenozoic inversion observed on seismic sections. Thus, it appears that Neogene-Pleistocene uplift did not influence the Bornholm area significantly. The data from the Höganäs Basin and Fyledal indicate a total uplift of $c .1450-2450 \mathrm{~m}$, corresponding to estimates from the inversion zone in the Kattegat. The data from Anholt, on the eastern margin of the inversion zone, indicate c. $975 \mathrm{~m}$ of uplift.
\end{abstract}

Keywords: Danish Basin, Fennoscandian Border Zone, Lower-Middle Jurassic, organic maturity, coalification curve, burial depth, Late Cretaceous - Early Tertiary inversion, Neogene-Pleistocene uplift

Geological Survey of Denmark and Greenland, Geocenter Copenhagen, Øster Voldgade 10, DK-1350 Copenhagen K, Denmark. E-mail: bip@geus.dk

Maturation of organic matter with increasing temperature is one of the most important parameters when evaluating the thermal history and hydrocarbon potential of a basin. A common way to assess the maturation depthtrend is to construct coalification curves by plotting measured huminite/vitrinite reflectances against depth. Various attempts have been made to construct such curves for the Danish Basin and the Fennoscandian Border Zone (Thomsen 1980; Thomsen et al. 1983, 1987; Schmidt 1985). However, these attempts have to some extent overlooked the significant amounts of post-Early Cretaceous differential uplift that have influenced the Danish Basin and the Fennoscandian Border Zone.

Forchhammer (1835) recognised the pronounced erosional unconformity at the base of the Quaternary. The hiatus at this surface increases significantly towards the northern and eastern margin of the Danish Basin. It is now widely accepted that significant regional uplift occurred in Neogene and Pleistocene times in the North Atlantic area and along the Norwegian west coast into the 


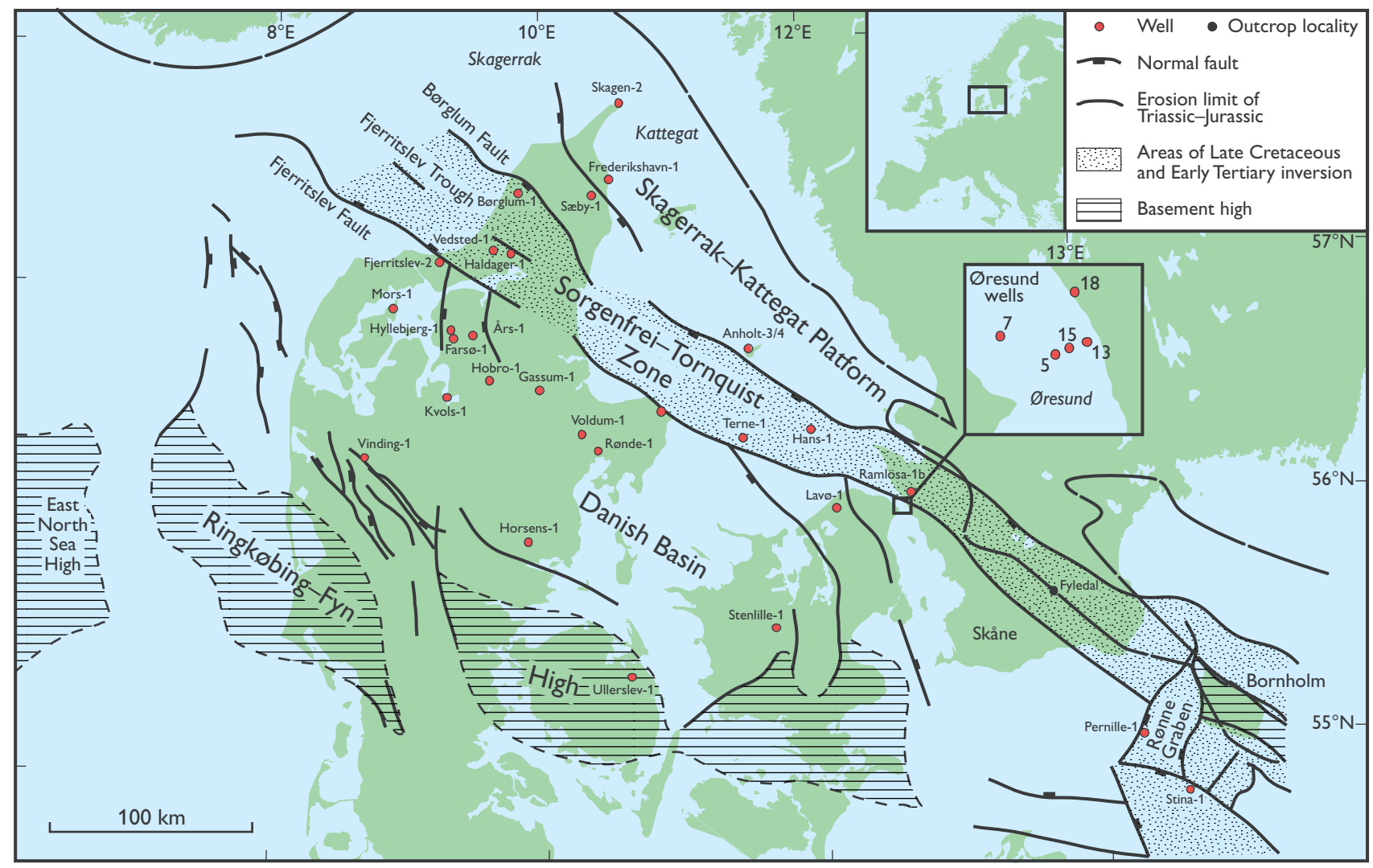

Fig. 1. Structural map showing the Danish Basin and the Fennoscandian Border Zone, and locations of the study wells and the outcrop at Fyleverken Sand Pit, Fyledal, Skåne (see also Fig. 9). Inset map shows the location of the wells in the Helsingør-Helsingborg area. Studied wells and outcrops on Bornholm are shown in Fig. 6. Modified from Liboriussen et al. (1987) and EUGENO-S Working Group (1988).

Skagerrak and the Kattegat to the Swedish coast (Manum \& Throndsen 1978; Jensen \& Michelsen 1992; Jensen \& Schmidt 1992, 1993; Nyland et al. 1992; Japsen 1993, 1998; Michelsen \& Nielsen 1993). In addition to the regional Neogene-Pleistocene uplift, significant inversion occurred in the Sorgenfrei-Tornquist Zone in Late Cretaceous - Early Cenozoic times due to right-lateral transpression (Liboriussen et al. 1987; Norling \& Bergström 1987; EUGENO-S Working Group 1988; Michelsen \& Nielsen 1991, 1993; Mogensen 1994). The amount and distribution of the two types of uplift of the Danish Basin and Sorgenfrei-Tornquist Zone have been estimated by comparing the lateral variation of the sonic velocities of a uniform unit of Lower Jurassic marine mudstones with the structural and stratigraphic development of the area (Jensen \& Michelsen 1992; Japsen 1993; Michelsen \& Nielsen 1993). These estimates indicate uplift of 100-2000 $\mathrm{m}$, emphasising that variable amounts of uplift have to be considered when huminite/vitrinite reflectances are used to interpret the thermal history and predict maturity of undrilled sections. We have used 311 reflectance measurements (corrected for uplift) from 20 well-sections
(Fig. 1) in order to construct a reliable coalification curve which can be used to evaluate the thermal history and maturation of organic matter in the Danish Basin and the Fennoscandian Border Zone. The amount of uplift was primarily estimated from seismic interval velocities (Japsen 1993). The aims of the paper are: (1) to construct a regional coalification curve for the Danish Basin and the Fennoscandian Border Zone and (2) to use the curve to estimate the burial depth and later uplift of Lower-Middle Jurassic strata exposed or cored in shallow wells in the Fennoscandian Border Zone by comparing huminite reflectances with the curve. The maturation of organic matter provides the best estimate of the burial and uplift history, as measurements of sonic velocities in general are not available from these localities.

\section{Geological setting}

The Fennoscandian Border Zone is divided into the Skagerrak-Kattegat Platform and the Sorgenfrei-Tornquist Zone (Fig. 1; Sorgenfrei \& Buch 1964; EUGENO-S 
Fig. 2. Stratigraphic scheme of the Lower-Middle Jurassic of the Danish Basin, Bornholm and Skåne. Compiled from Nielsen (1995; 2003, this volume), Ahlberg et al. (2003, this volume) and Michelsen et al. (2003, this volume).

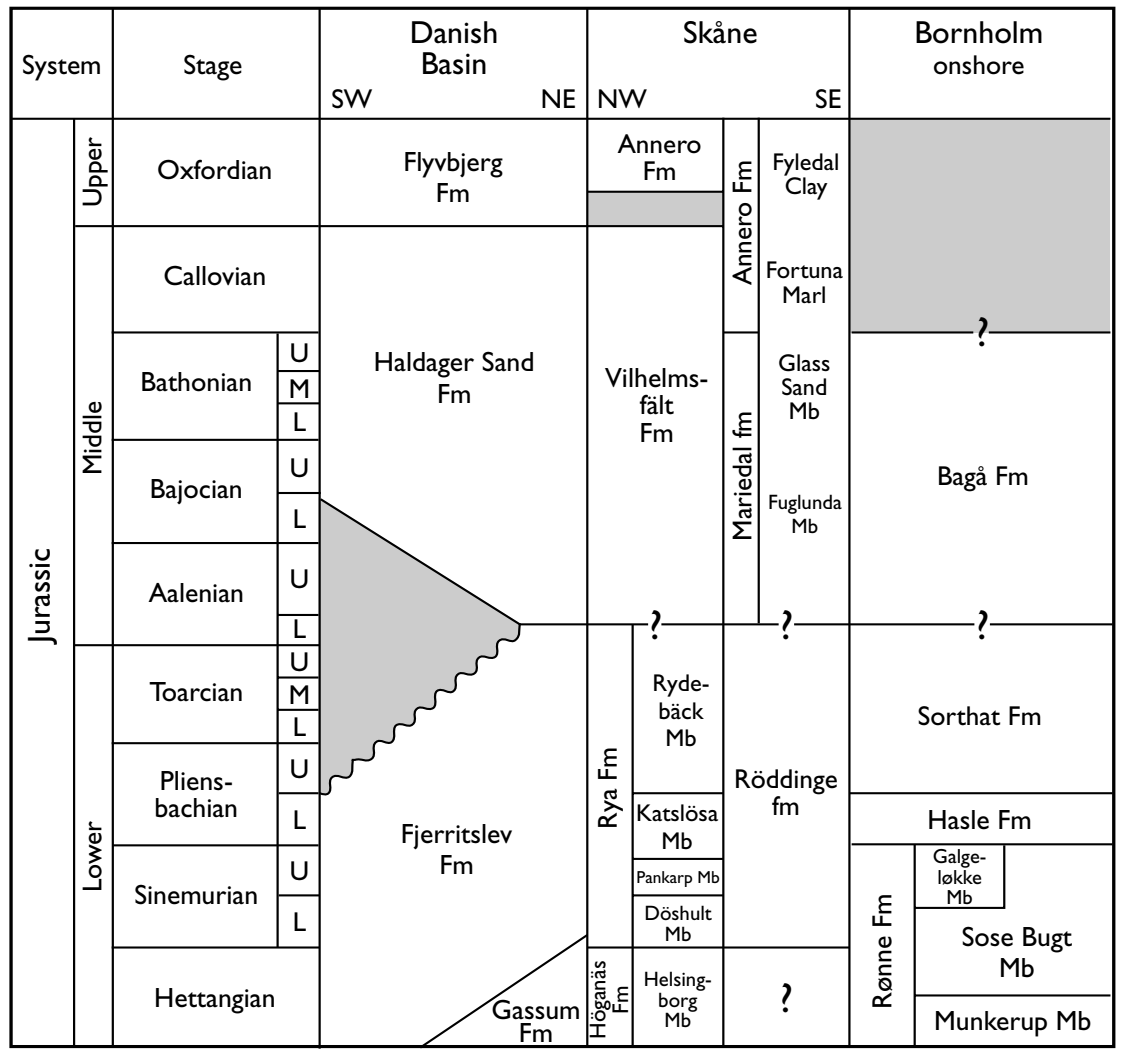

Working Group 1988; Michelsen \& Nielsen 1991, 1993). The Skagerrak-Kattegat Platform is a large stable platform area to the north-east where the Mesozoic succession onlaps Palaeozoic and crystalline basement rocks and thins towards the north-east. The Sorgenfrei-Tornquist Zone is $20-50 \mathrm{~km}$ wide and strongly block-faulted. The zone demarcates the stable Baltic Shield and forms the north-western extension of one of Europes most prominent tectonic structures, the Tornquist Zone. The Sorgenfrei-Tornquist Zone converges at the Rønne Graben, offshore Bornholm, with the Teisseyre-Tornquist Zone which constitutes a tectonic lineament extending to the Black Sea (Ziegler 1982). The Rønne Graben is a pull-apart basin that formed by dextral wrench-faulting in Late Carboniferous - Early Permian times (Vejbæk 1985; Liboriussen et al. 1987). During the Late Palaeozoic - Mesozoic breakup of the supercontinent Pangaea, the Tornquist Zone was dominated by transtensional stress resulting in subsidence and tilting of fault blocks, and deposition of Mesozoic sedimentary successions up to $8 \mathrm{~km}$ thick.

The Sorgenfrei-Tornquist Zone demarcates the transition from the Baltic Shield to the WNW-ESE-trending intracratonic Danish Basin that was formed during a Late Carboniferous - Early Permian rift phase accompanied by formation of both extrusive and intrusive volcanic rocks. After rifting, the basin subsided due to thermal cooling (Sørensen 1986; Vejbæk 1989, 1990). The postrift basin-fill consists of a relatively complete section of Zechstein, Mesozoic and Cenozoic deposits which are 6-7 km thick along the axis of the basin. A gradual shallowing of the basin towards the high-lying basement blocks of the Ringkøbing-Fyn High to the south-west is indicated by thinning of the section. This is most pronounced for the Upper Permian (Zechstein) strata. The Ringkøbing-Fyn High was periodically subjected to erosion. In the Fjerritslev Trough, within the Sorgenfrei-Tornquist Zone, an important thickness anomaly was formed due to transtensional strike-slip movements possibly accompanied by salt withdrawal causing relatively fast subsidence and deposition (Bertelsen 1980; Liboriussen et al. 1987; Vejbæk 1990; Christensen \& Korstgård 1994). Late Early Jurassic - early Middle Jurassic uplift of the Ringkøbing-Fyn High, presumably connected to the updoming of the Central North Sea, caused north-eastwards tilting of the basin and erosion both on the high and in the southern part of the basin (Michelsen 1978; Koch 1983; Nielsen 1993 , 1995, 2003, this volume). Extensive volcanism and uplift occurred in Skåne, possibly connected to general updoming (Klingspor 1976; Norling \& Bergström 1987; F. Surlyk, personal communication 1996). In late Middle 


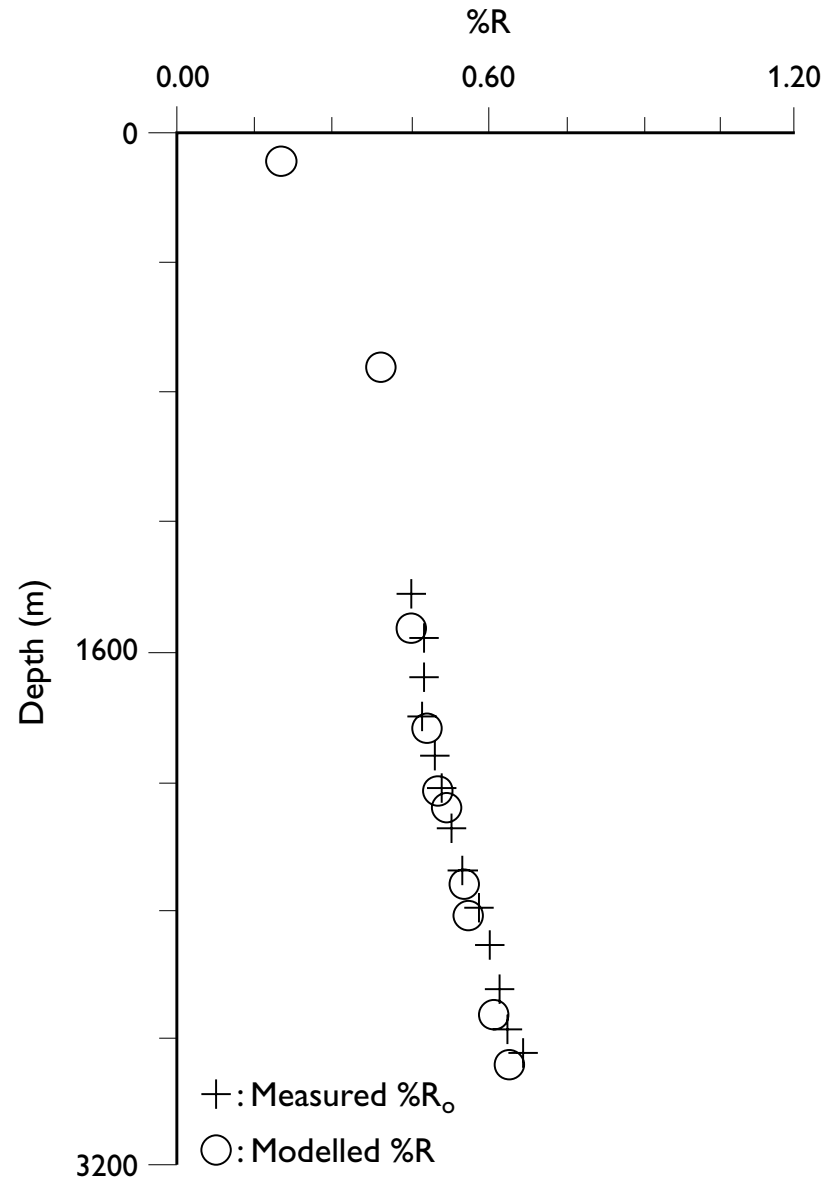

Fig. 3. Modelled reflectance values and selected measured reflectance values from the Hyllebjerg- 1 well. The uplift determined by basin modelling is $600 \mathrm{~m}$ compared to $575 \mathrm{~m}$ obtained from shale velocities. This confirms that the area around Hyllebjerg-1 is a good reference area.

- Late Jurassic times, the Ringkøbing-Fyn High began to subside again and gradually the basin expanded towards the south-west, attaining its previous size towards the end of the Early Cretaceous (Nielsen 1995).

During Late Cretaceous - Early Cenozoic times, transpressional tectonism in the Sorgenfrei-Tornquist Zone and the Rønne Graben, caused by the Alpine orogenesis, led to reactivation and pronounced inversion of fault blocks in the zone, which together with NeogenePleistocene regional uplift resulted in erosion of the Mesozoic deposits (Gry 1969; Gravesen et al. 1982; Liboriussen et al. 1987; Norling \& Bergström 1987; Japsen 1993, 1998; Michelsen \& Nielsen 1991, 1993).

The Lower-Middle Jurassic stratigraphy of the Danish Basin, Bornholm and Skåne is shown in Figure 2. Note that the Upper Pliensbachian - Lower Aalenian section on Bornholm has previously been referred to the lower
Bagå Formation (Koppelhus \& Nielsen 1994), but is now assigned to the Sorthat Formation (Michelsen et al. 2003, this volume).

\section{Prerequisites for construction of a regional coalification curve}

Construction of a regional coalification curve requires that the following conditions are fulfilled: (1) many geographically widespread data, (2) exclusion of data from well-sections with an abnormal thermal history, (3) reliable corrections for uplift and (4) a relatively constant temperature gradient both in time and space.

Although totalling more than 300 , the reflectance measurements from the Triassic - Lower Cretaceous deposits in the Danish Basin and the Fennoscandian Border Zone only partly fulfil the first condition (Fig. 1). Close to half of the data points come from the central part of the basin from wells such as Mors-1, Hyllebjerg-1, Års-1 and Fars $\varnothing-1$. However, this is not a serious problem because in this area there is good agreement between uplift values determined from shale velocities and results from modelling of the maturation history. For example, in the Hyllebjerg-1 well (Fig. 3), the uplift determined by basin modelling is $600 \mathrm{~m}$ compared with $575 \mathrm{~m}$ obtained from shale velocities.

Reflectance values from deposits directly overlying salt diapirs clearly indicate a locally increased heat flow (Uglev-1; Schmidt 1985), and have been omitted in the construction of the regional curve.

The corrections for uplift of the selected well-sections have been mainly calculated from seismic velocity data (Japsen 1993). The amount of correction is further controlled by the well-known stratigraphy and structures of the area as shown by interpreted seismic sections and preserved thicknesses of lithostratigraphic units in wellsections.

The basin subsided due to thermal contraction after the Permian rift phase with raised heat flow (Vejbæk 1989). The initial phase of the basin development was probably characterised by lateral variations in heat flow, but after the deposition of a thick sedimentary cover of Zechstein and Lower-Middle Triassic deposits, the lateral variations in heat flow probably ceased due to the effect of sediment blanketing (Nielsen \& Balling 1990). Recent mapping and modelling of the subsurface temperature at various depths demonstrate a uniform regional temperature distribution in the study area (J.J. Møller, personal communication 1997). Furthermore, regional corrected measurements of heat flow at the sur- 
face are uniform, in the range $60-70 \mathrm{~mW} / \mathrm{m}^{2}$ (Balling 1995). Based on the structural and thermal evolution of the basin, therefore, we assume that the lateral variation in heat flow from Late Triassic to Recent times in general was relatively small, and that lateral heat flow variations did not influence the maturation of the organic matter significantly.

The necessary prerequisites for the construction of a regional coalification curve are thus fulfilled to a large extent. In order to avoid complications due to the late Early Jurassic - Middle Jurassic uplift of the Ringkøbing-Fyn High and the southern parts of the basin, the majority of the data used for construction of the curve comes from well-sections that experienced continued subsidence or only limited uplift and erosion during this phase (Nielsen 1995).

\section{Influence of temperature on maturation}

The increase in rank with depth in a well-section is mainly caused by rising temperature with depth, and the rate of rank increase is strongly dependent on the geothermal gradient. In a sandstone succession, for instance, the rank gradient is much lower than in a mudstone succession due to the higher thermal conductivity of sandstones (Damberger 1968). Raised heat flow and thus a higher geothermal gradient also raises the rank gradient (Teichmüller 1979; Suggate 1998). However, in a basin with a relatively constant heat flow and a laterally uniform lithology, the rank of coals is primarily dependent on the maximum temperature to which the organic matter was subjected, which corresponds to the maximum burial depth. Since coalification of organic matter is irreversible, later uplift does not influence the measured reflectance values.

As demonstrated below, the majority of the reflectance values from the Danish Basin and the Fennoscandian Border Zone are interpreted to show a normal coalification trend. The rank of the coals thus reflects the maximum burial depth of the strata.

\section{Construction of the coalification curve}

A total of 311 reflectance measurements from the Upper Triassic, Jurassic and Lower Cretaceous successions in twenty wells from the Fennoscandian Border Zone and the Danish Basin are used in the construction of the coalification curve (Fig. 1). All the reflectance values are random measurements. Samples from drill cores were available from the Frederikshavn-1, Fjerritslev-2, Gassum-1, Haldager-1, Horsens-1, Lavø-1, Skagen-2, Ullerslev-1, Vedsted-1 and Vinding-1 wells. Where possible, samples with coal, coaly inclusions, or dark-coloured shales or siltstones were selected for reflectance measurements as these rocks contain the best organic matter for rank determination (Thomsen 1980). Untreated rock samples were studied as they more easily allow identification of oxidised and bituminous organic matter (unsuitable for reflectance measurements) than is the case for kerogen concentrates. In coal or coaly samples, approximately 50-100 measurements were carried out in each sample; in samples with disseminated organic matter, as many particles as possible were measured, usually 20-50. Core samples from the Børglum-1 well were analysed in the same fashion (Schmidt 1985), whereas coaly or dark-coloured shaly intervals were selected from sidewall cores and core samples in the Farsø-1 well (Thomsen 1983). Cuttings and a limited number of core samples were available from the Års-1 well, whereas only cuttings were available from the rest

Table 1. Correction for post-Early Cretaceous uplift

\begin{tabular}{|c|c|c|}
\hline $\begin{array}{r}\mathrm{T} \\
\mathrm{C} \\
\text { (amc }\end{array}$ & $\begin{array}{l}\text { tal post-Early } \\
\text { taceous uplift } \\
\text { nt of correction) }\end{array}$ & $\begin{array}{l}\text { Comments on } \\
\text { the estimated } \\
\text { amounts of uplift }\end{array}$ \\
\hline Års-1 & $558 \mathrm{~m}$ & After Japsen (1993) \\
\hline Børglum-1 & $1273 \mathrm{~m}$ & After Japsen (1993) \\
\hline Farsø-1 & $481 \mathrm{~m}$ & After Japsen (1993) \\
\hline Fjerritslev-2 & $1531 \mathrm{~m}$ & After Japsen (1993) \\
\hline Frederikshavn-1 & $1000 \mathrm{~m}$ & $\begin{array}{l}\text { By comparison to Sæby-1, } 997 \text { m } \\
\text { (Japsen 1993) }\end{array}$ \\
\hline Gassum-1 & $1190 \mathrm{~m}$ & $\begin{array}{l}\text { By comparison to Voldum-1, } 942 \mathrm{~m} \\
\text { (Japsen 1993) and } 248 \mathrm{~m} \text { deeper } \\
\text { truncation of chalk }\end{array}$ \\
\hline Haldager-1 & $1400 \mathrm{~m}$ & $\begin{array}{l}\text { By comparison to Børglum-1 and } \\
\text { Fjerritslev-2 }\end{array}$ \\
\hline Hans-1 & $1733 \mathrm{~m}$ & After Japsen (1993) \\
\hline Hobro-1 & $550 \mathrm{~m}$ & By comparison to Års-1 \\
\hline Horsens-1 & $200 \mathrm{~m}$ & By using fig. 1C in Japsen (1993) \\
\hline Hyllebjerg-1 & $575 \mathrm{~m}$ & After Japsen (1993) \\
\hline Kvols-1 & $448 \mathrm{~m}$ & After Japsen (1993) \\
\hline Lavø-1 & $1000 \mathrm{~m}$ & $\begin{array}{l}\text { By using fig. } 1 \mathrm{C} \text { in Japsen (1993) } \\
\text { and Stenlille-1, } 850 \mathrm{~m}\end{array}$ \\
\hline Mors-1 & $785 \mathrm{~m}$ & After Japsen (1993) \\
\hline Rønde-1 & $513 \mathrm{~m}$ & After Japsen (1993) \\
\hline Skagen-2 & $1100 \mathrm{~m}$ & By comparison to Sæby-1, $997 \mathrm{~m}$ \\
\hline Terne-1 & $1405 \mathrm{~m}$ & After Japsen (1993) \\
\hline Ullerslev-1 & $500 \mathrm{~m}$ & By using fig. 1C in Japsen (1993) \\
\hline Vedsted-1 & $1400 \mathrm{~m}$ & $\begin{array}{l}\text { By comparison to Børglum-1 and } \\
\text { Fjerritslev- } 2\end{array}$ \\
\hline Vinding-1 & $250 \mathrm{~m}$ & $\begin{array}{l}\text { By comparison to Mejrup-1, } 327 \mathrm{~m} \text {, } \\
\text { and Vemb-1, } 309 \mathrm{~m} \text { (Japsen 1993) }\end{array}$ \\
\hline
\end{tabular}



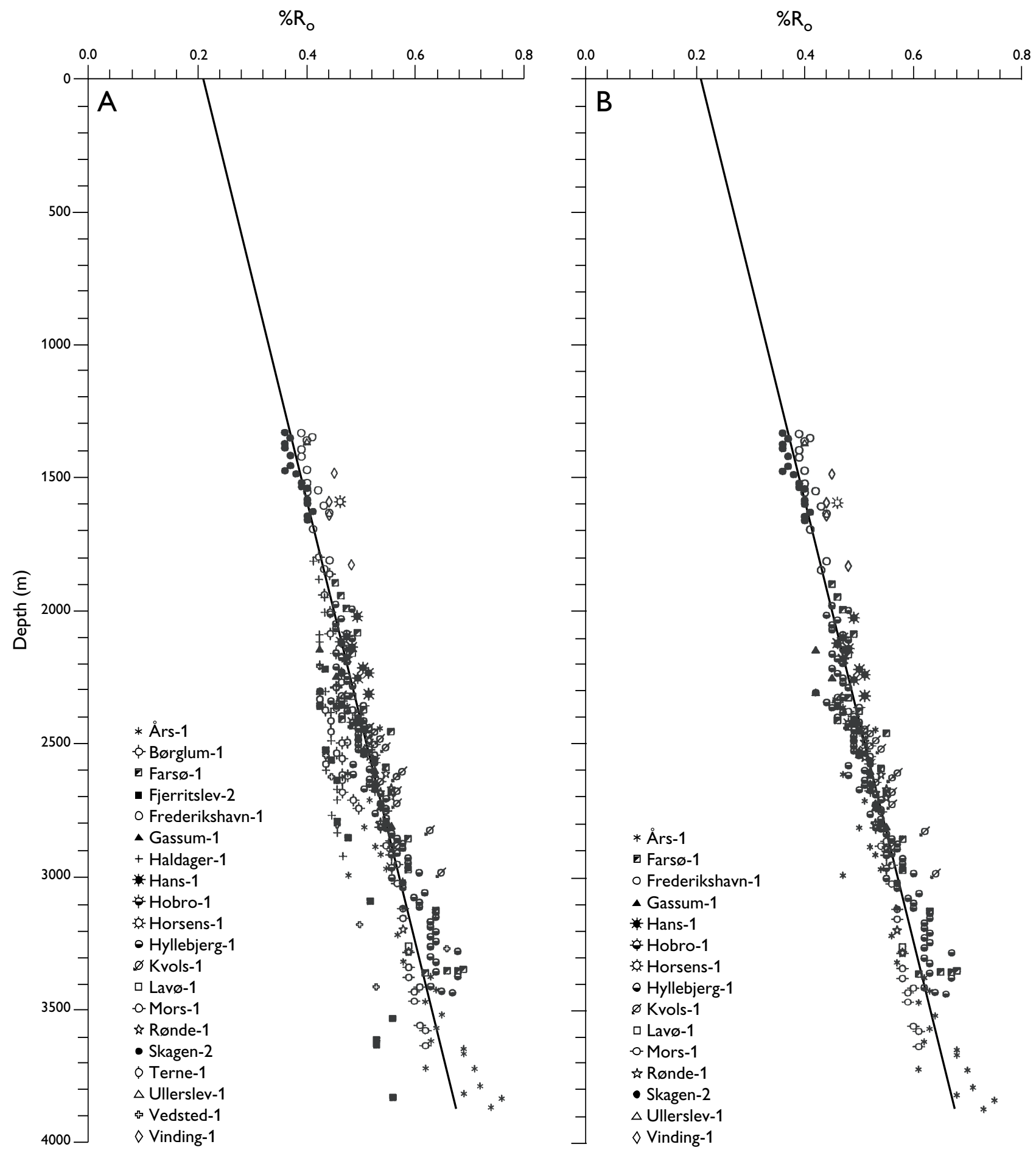

Fig. 4. A: Coalification profile for the 20 investigated wells $(n=311)$; the depths are corrected for post-Cretaceous uplift. Data from Thomsen (1980, 1983, 1984), Schmidt (1985, 1988) and unpublished GEUS data. B: Coalification profile (uplift-corrected depths) for 15 wells in the Danish Basin, the Fennoscandian Border Zone and the Skagerrak-Kattegat Platform $(n=249)$. The regression line has a correlation coefficient of 0.88 , and intercepts the reflectance axis at $0.21 \% \mathrm{R}_{0}$.

of the wells (Rønde-1: Thomsen 1980; Hyllebjerg-1: Schmidt 1988; Hans-1, Hobro-1, Kvols-1, Mors-1, Terne-1: GEUS, unpublished data). All sample depths were corrected for post-Early Cretaceous net uplift before being plotted against reflectance (Table 1). The correction for the well-sections was based on the analysis of sonic velocities of shales by Japsen (1993). The main uncertainties related to this method are the requirement 
of a uniform shale unit covering the entire study area and a valid reference curve (discussed in Japsen 1993).

The analyses of the velocity data provide an uplift pattern that is compatible with structural interpretations of seismic sections and stratigraphic well data. The present sample depths are thus corrected by adding the amount of uplift proposed by Japsen (1993). The uplift of wells not included by Japsen (1993) is estimated by comparison to nearby wells and interpolation (Table 1). The Gassum-1 well, for example, is situated on a salt structure, in a setting comparable to the nearby Voldum-1 well, which was uplifted $942 \mathrm{~m}$ (Japsen 1993). The chalk section in Gassum-1 seems to be more deeply truncated than that in Voldum-1 (c. $250 \mathrm{~m}$ ), and an uplift of c. $1190 \mathrm{~m}$ is thus estimated for the Gassum- 1 section. The uplift of the Horsens-1 and Ullerslev-1 wells is estimated to be $200 \mathrm{~m}$ and $500 \mathrm{~m}$, respectively, by using the general uplift map of Japsen (1993). The uplift of the Lavø-1 well is estimated to be $1000 \mathrm{~m}$ based on the same map and comparison with the Stenlille-1 well (850 m).

Two coalification trends are recognised when the reflectance measurements are plotted against uplift-corrected depths: a well-defined main trend to the right and a less pronounced trend to the left (Fig. 4A). The main coalification trend is based on well data from the Danish Basin and the Skagerrak-Kattegat Platform (Fig. $4 \mathrm{~B})$, whereas well data from the Fjerritslev Trough (Børglum-1, Fjerritslev-2, Haldager-1, Vedsted-1) and the Terne-1 well define the other coalification trend.

Huminite/vitrinite reflectance is largely unaffected by the formation of mainly isolated aromatic rings up to a reflectance of $c .0 .7 \% \mathrm{R}_{\mathrm{o}}$, resulting in a slow and more or less linear increase in reflectance (Carr \& Williamson 1990; Suggate 1998). However, as maturation proceeds past this point the formation of polycyclic aromatic units significantly increases the reflectance. As the level of coalification in the studied sections is in the low rank range $\left(<0.7 \% \mathrm{R}_{\mathrm{o}}\right)$, it is possible to approximate this 'straight' section of the curve with a linear regression line. The linear regression line for the Danish Basin/Skagerrak-Kattegat Platform intersects the $\% \mathrm{R}_{\mathrm{o}}$-axis at $0.2 \% \mathrm{R}_{\mathrm{o}}$, which is the expected reflectance at the surface (Fig. 4B; Dow 1977; Suggate 1998). The rank gradient is $0.12 \% \mathrm{R}_{\mathrm{o}} / \mathrm{km}$. The absence of significant anomalies indicates that the assumption of a relatively uniform geothermal gradient in the study area is justified, and that the corrections for uplift are reasonable. The regression line of the coalification curve is based on 249 samples; it has a correlation coefficient of 0.88 , and is considered to be a good approximation of the coalification profile. This relationship can then

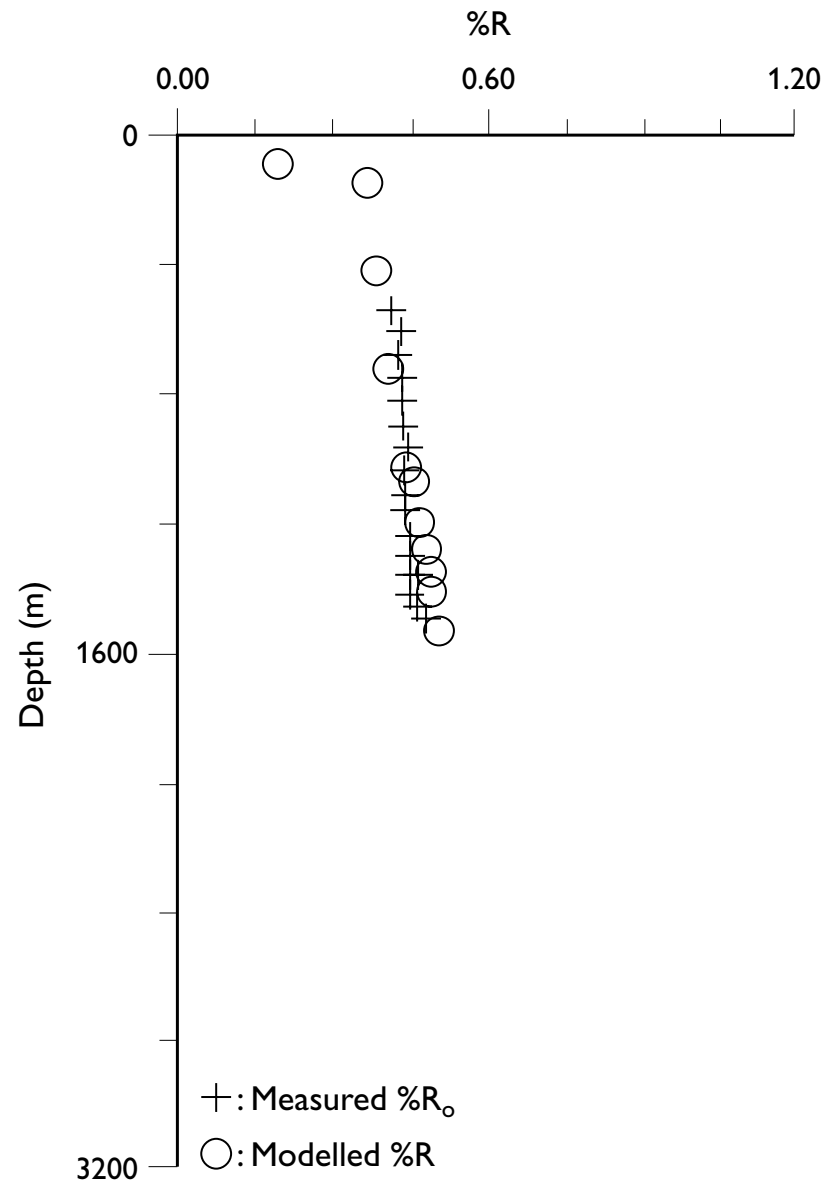

Fig. 5. Modelled reflectance values and measured reflectance values from the Børglum-1 well. The amount of uplift determined by basin modelling is $800 \mathrm{~m}$ compared to the $1300 \mathrm{~m}$ obtained from shale velocities. It is suggested that the uplift of the wells in the Fjerritslev Trough (and the Terne-1 well) determined from the shale velocities is overestimated due to the sand-rich nature of the succession in these wells.

be used to estimate the maximum burial depths and later uplift of Jurassic coal seams in the Fennoscandian Border Zone. The reasonable and stratigraphically consistent estimates are taken as indirect evidence of the reliability of the coalification curve, and the coalification curve is considered as a valid approximation of the maturation trend over most of the study area.

The data from Børglum-1, Fjerritslev-2, Haldager-1, Vedsted-1 and Terne- 1 form an atypically steep coalification trend which was investigated by modelling of the basin development. Modelled vitrinite reflectances for the Børglum-1 well are shown in Figure 5, together with the measured values. The basin modelling indicates uplift of only $800 \mathrm{~m}$, compared with $1300 \mathrm{~m}$ derived from shale velocities. Interval velocities for the 
chalk section in the Fjerritslev Trough are low, and new data based on Chalk Group velocities yield significantly lower uplift values (Japsen 1998). The data suggest correction for uplift of only $817 \mathrm{~m}$ for Børglum-1, $1012 \mathrm{~m}$ for Fjerritslev-2, and $644 \mathrm{~m}$ for Haldager-1. If the present depths of these wells are uplift-corrected according to the new Chalk Group data, the huminite reflectance values would fit the coalification curve shown in Figure 4B.

This suggests that uplift values determined from shale velocities are probably overestimates. The relatively high shale velocities in this area (Japsen 1993) may be the result of an increased coarse-grained component within the lowermost Fjerritslev Formation than is typical of the rest of the basin.

\section{Estimation of burial depth and later uplift of Lower-Middle Jurassic coal seams in the Fennoscandian Border Zone}

\section{Determination of coal rank}

The rank, or the level of thermal maturity, of the coals was determined by random reflectance measurements on eu-ulminite, the brown coal equivalent of collotelinite, following the standard procedure outlined in Taylor et al. (1998). Up to 100 measurements were made on each sample and a mean reflectance $\left(\% \mathrm{R}_{\mathrm{o}}\right)$ was calculated. Parameters obtained by organic geochemical methods, when available, were used to support the estimation of the maturity.

Rock-Eval pyrolysis was used to determine the $T_{\max }$ value which is the temperature at which maximum pyrolysis occurs (Peters 1986). The value of $T_{\max }$ increases with increasing maturity of the organic matter, but is also influenced by the composition of the organic matter, as a high content of inert components may result in an elevated $T_{\max }$ value.

Biomarker data were obtained from the saturated fraction of solvent extracts from the coal samples using gas chromatography/mass spectrometry. Pentacyclic hopanes were identified by detecting the most characteristic fragmentation ion, the $\mathrm{m} / \mathrm{z} 191$. The occurrence of the thermally unstable hopenes and $17 ß(\mathrm{H}), 21 ß(\mathrm{H})$ forms in the coals is indicative of immaturity, and the $\mathrm{C}_{31}$-homohopane $22 \mathrm{~S} /(22 \mathrm{R}+22 \mathrm{~S})$ epimerisation ratio approaches an equilibrium value of approximately 0.6 with increasing maturity. The sensitivity of the hopanes to thermal influence at low maturity levels may be a valuable criterion when evaluating the validity of maturity differences obtained by reflectance measurements.

The carbon preference index (CPI) was calculated from traces obtained from gas chromatography. The $\mathrm{CPI}$ is a measure of the predominance of odd carbon numbered $n$-alkanes calculated over a specified range (Bray \& Evans 1961; Cooper \& Bray 1963). In the present study, the range was from $n \mathrm{C}_{22}$ to $n \mathrm{C}_{32}$. The dominance of odd carbon numbered $n$-alkanes together with a prominent heavy-end fraction are characteristic features of terrestrially derived organic matter (Isaksen 1995). However, increasing maturity seems to minimise the CPI due to alkane cleavage reactions and dilution of the odd carbon numbered $n$-alkanes (Radke et al. 1980). Hence, the CPI tends to reach an equilibrium of 1 with increasing maturity.

\section{Huminite reflectances of the coals}

The following section focuses on the degree of coalification of Lower and Middle Jurassic coal seams and strata from the island of Bornholm, the Rønne and Kolobrzeg Grabens (offshore Bornholm), Skåne, the $\varnothing$ resund area, and Kattegat in order to present the rank distribution.

\section{Hettangian-Sinemurian Rønne Formation, Bornholm}

Two coal seams in the Hettangian Munkerup Member of the Rønne Formation in the Arnager-Sose Fault Block have reflectances of $0.40 \% \mathrm{R}_{\mathrm{o}}$ and $0.41 \% \mathrm{R}_{\mathrm{o}}$ (Figs 2, 6; Table 2). However, samples from carbonaceous seams in the overlying Hettangian-Sinemurian Sose Bugt Member display significantly lower reflectance values $\left(0.28 \% \mathrm{R}_{\mathrm{o}}\right.$ and $0.30 \% \mathrm{R}_{\mathrm{o}}$ ) (Figs 2, 6; Table 2).

The coal seam in the Sinemurian Galgeløkke Member of the Rønne Formation at the Galgeløkke coastal cliff (Rønne-Hasle Fault Block) has a reflectance of 0.38 $\% \mathrm{R}_{\mathrm{o}}$ (Figs 2, 6; Table 2). The Galgeløkke-2 well was drilled close to the Galgeløkke cliff and cored c. $400 \mathrm{~m}$ of Hettangian-Sinemurian strata (Nielsen 1995). A Hettangian coal seam situated at a depth of $383 \mathrm{~m}$ has a reflectance value of $0.42 \% \mathrm{R}_{\mathrm{o}}$. This is compatible with a $T_{\max }$ value of $427^{\circ} \mathrm{C}$ and a $\mathrm{C}_{31}$-homohopane $22 \mathrm{~S} /(22 \mathrm{~S}+22 \mathrm{R})$ epimerisation ratio of only 0.06 . The coal seam is estimated to lie $50-75 \mathrm{~m}$ above the base of the Jurassic, as suggested by log correlations between the Galgeløkke-2, Pernille-1 and Stina-1 wells (Nielsen 1995). 
Fig. 6. Geological map of Bornholm showing the investigated localities: 1, exposed Munkerup Member (Rønne Formation); $\mathbf{2}$, type section of the Sose Bugt Member (Rønne Formation); 3, type section of the Galgeløkke Member (Rønne Formation) at the Galgeløkke coastal exposures and the Galgeløkke-2 well; 4, Korsodde coastal cliff, Sorthat Formation; 5, Levka-1 well, Sorthat Formation; 6, Hasle Klinkerfabrik clay pit, upper Bagå Formation. Modified from Gravesen et al. (1982).

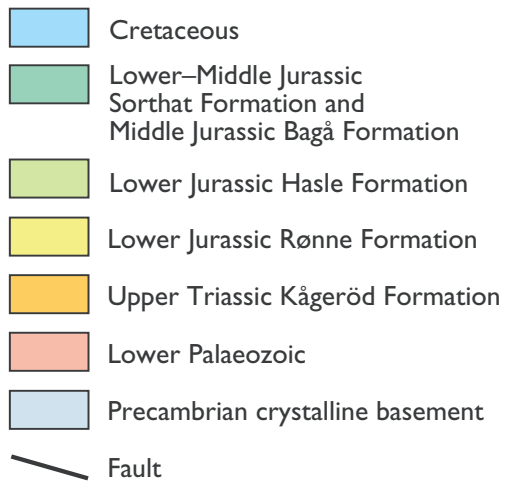

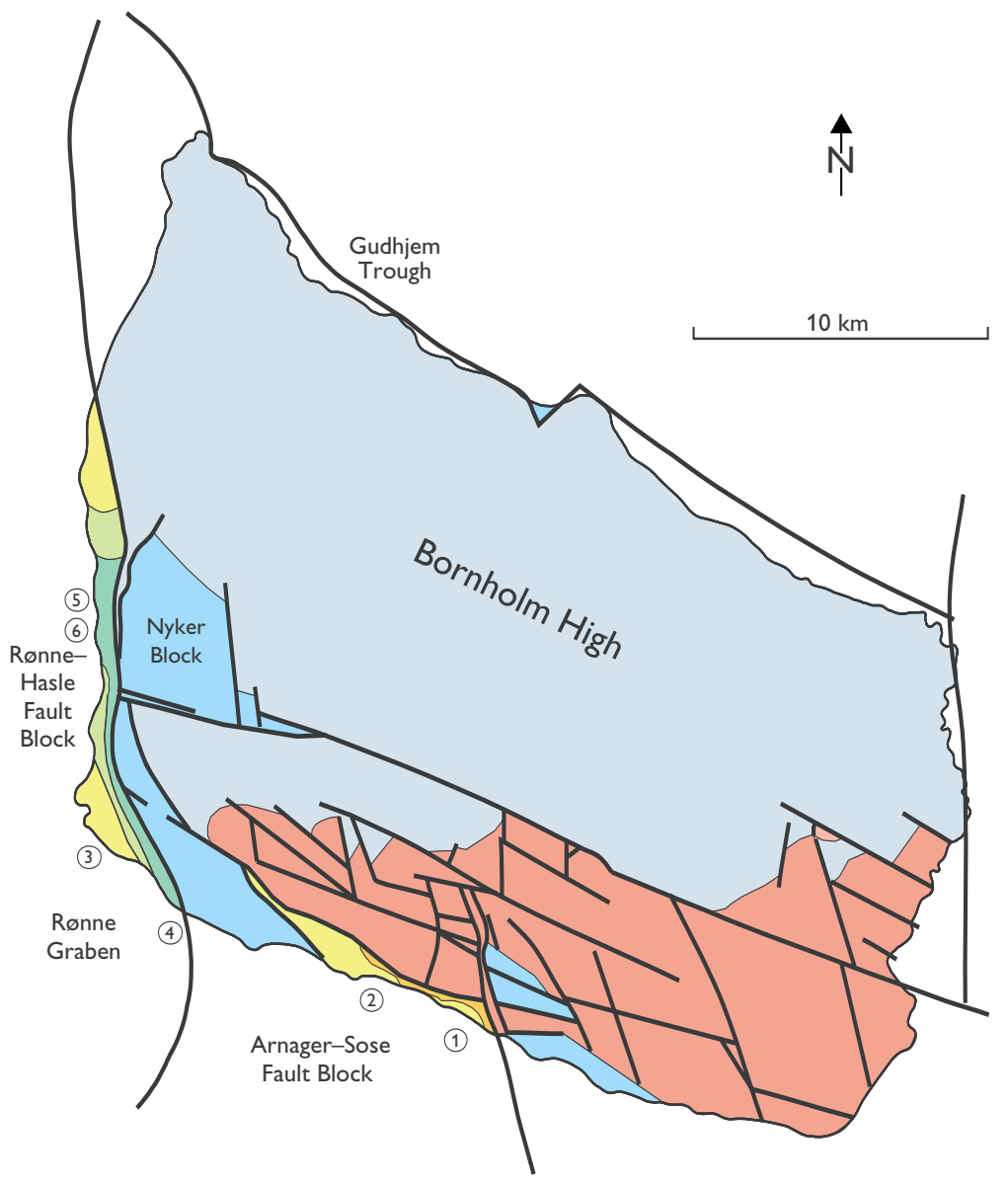

Table 2. Maturity data, estimated burial depth/magnitude of later uplift

\begin{tabular}{|c|c|c|c|c|c|c|c|}
\hline Locallity & Age & $\begin{array}{c}\text { Average } \\
\text { reflectance } \\
\% R_{o}^{\#} \\
\end{array}$ & $\begin{array}{c}\text { Number of } \\
\text { mean random } \\
\text { reflectances }\end{array}$ & $\begin{array}{c}\text { Average } T_{\max } \\
\left(\mathrm{C}^{\circ}\right) \\
(\mathrm{n}) \\
\end{array}$ & $\begin{array}{l}\mathrm{C}_{31} \text {-homohopane } \\
22 \mathrm{~S} /(22 \mathrm{~S}+22 \mathrm{R})\end{array}$ & $\begin{array}{l}\text { Maximum } \\
\text { burial depth } \\
(\mathrm{m})\end{array}$ & $\begin{array}{l}\text { Net uplift } \\
\text { (m) }\end{array}$ \\
\hline Sose Bugt section & Hettangian-Sinemurian & 0.29 & 2 & - & - & 625 & $625^{++}$ \\
\hline Anholt well* & Lower Jurassic & 0.33 & 12 & - & - & 975 & 975 \\
\hline $\begin{array}{l}\text { Levka-1 well / } \\
\text { Korsodde section** }\end{array}$ & $\begin{array}{l}\text { Upper Pliensbachian - } \\
\text { Lower Toarcian }\end{array}$ & 0.36 & 13 & $420(60)$ & $0.06-0.1$ & 1210 & 1210 \\
\hline Øresund-15 well ${ }^{+}$ & Sinemurian & 0.36 & 1 & $419(1)$ & - & 1210 & 1210 \\
\hline Galgeløkke section & Sinemurian & 0.38 & 2 & - & - & 1400 & 1400 \\
\hline Øresund-5 well ${ }^{+}$ & Bajocian & 0.39 & 1 & $421(2)$ & - & 1450 & 1450 \\
\hline Fyleverken Sand Pit & Bajocian & 0.39 & 2 & $430(2)$ & - & 1450 & 1450 \\
\hline Munkerup section & Hettangian & 0.41 & 2 & - & - & 1660 & 1660 \\
\hline Galgeløkke-2 well & Hettangian & 0.42 & 1 & $427(1)$ & 0.06 & 1700 & 1320 \\
\hline Hasle KI. Clay Pit & Bathonian & 0.42 & 6 & - & - & 1700 & 1700 \\
\hline Øresund-7 well $^{+}$ & Bajocian-Bathonian & 0.43 & 5 & $418(9)$ & $0.05-0.09$ & 1875 & 1875 \\
\hline Øresund-13 well ${ }^{+}$ & Hettangian-Sinemurian & 0.46 & 1 & $426(1)$ & 0.23 & 2100 & 2010 \\
\hline Øresund-18 well ${ }^{+}$ & Hettangian-Sinemurian & 0.51 & 2 & $426(7)$ & $0.37-0.42$ & 2440 & 2440 \\
\hline
\end{tabular}

\# The average reflectance is calculated from mean random reflectance (nos of analyses).

A mean random reflectance value is based on c. 100 measurements in each sample.

* Data from Nielsen et al. (2003, this volume).

** Data from Petersen \& Nielsen (1995).

+ Data from Petersen (1994).

++ Post-Early Cretaceous uplift: 290 m (Petersen et al. 1996) 
Upper Pliensbachian - Lower Toarcian part of the Sorthat Formation, Bornholm

Reflectance values of coal seams from the Upper Pliensbachian - Lower Toarcian part of the Sorthat Formation in cores from the Levka-1 well and in the Korsodde coastal cliff (Rønne-Hasle Fault Block) average 0.36 $\% \mathrm{R}_{\mathrm{o}}$ (Figs 2, 6; Table 2). $T_{\max }$ values average $421^{\circ} \mathrm{C}$, and $\mathrm{C}_{31}$-homohopane $22 \mathrm{~S} /(22 \mathrm{~S}+22 \mathrm{R})$ epimerisation ratios for eight samples from the Levka-1 well are in the range $0.06-0.1$, which conforms with low rank coals. Thermally sensitive hopenes and Bß-forms occur, and CPI values greater than 3 are compatible with immature low rank coals (Petersen \& Nielsen 1995).

\section{Bathonian part of the Bagå Formation, Bornholm}

The coal-bearing Aalenian-Bathonian Bagå Formation is exposed in the Hasle Klinkerfabrik Clay Pit (Figs 2, 6).
The clay pit is situated in the Rønne-Hasle Fault Block, close to the faulted margin of the Rønne Graben. Reflectance values from eight coal seams in the uppermost part of the Bagå Formation (Bathonian) are in the range $0.36-0.46 \% \mathrm{R}_{\mathrm{o}}$, averaging $0.42 \% \mathrm{R}_{\mathrm{o}}$ (Table 2 ).

\section{Lower Jurassic in the Rønne and Kolobrzeg Grabens}

The Lower Jurassic from the western part of the Rønne Graben is represented by the Pernille- 1 well, and from the Kolobrzeg Graben by the Stina-1 well (Fig. 7). In Pernille-1, the Lower Jurassic from $980-1470 \mathrm{~m}$ is referred to the Hettangian-Sinemurian Rønne Formation (Nielsen 1995). The reflectance values show a well-defined coalification trend with increasing depth (Fig. 8).

In Stina-1, the Lower Jurassic from $180-560 \mathrm{~m}$ possibly includes the Hettangian to Upper Pliensbachian (Nielsen 1995). The reflectance values vary between $0.31 \% \mathrm{R}_{\mathrm{o}}$ and $0.40 \% \mathrm{R}_{\mathrm{o}}$ (Fig. 8 ).

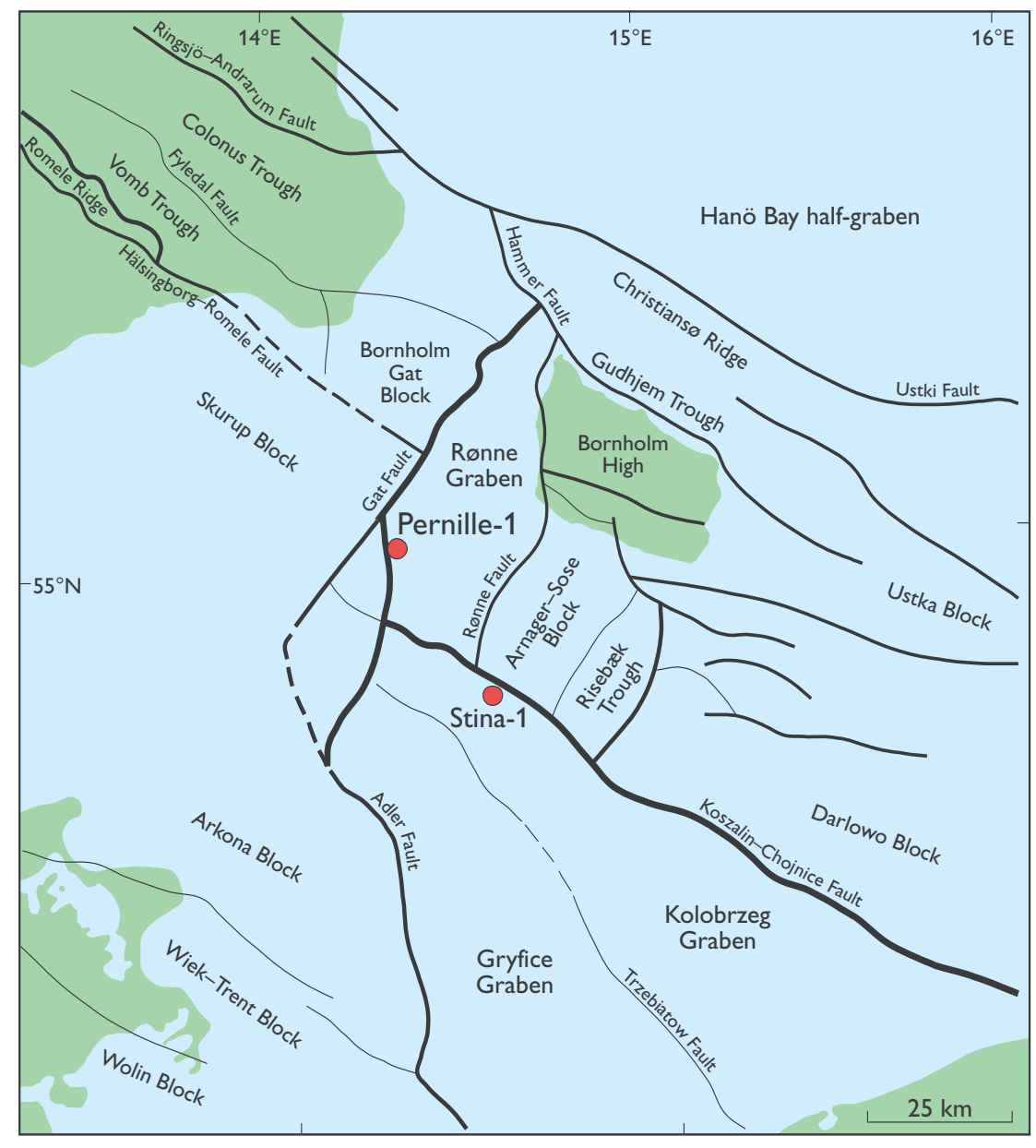

Fig. 7. Structural map showing the block mosaic of the Bornholm region and the position of the Pernille- 1 and Stina-1 wells. The relative significance of the faults is indicated by varying line thickness. Slightly modified from Hamann (1994). 


\section{Bajocian Fuglunda Member of Skåne}

Bajocian coal-bearing sediments of the Fuglunda Member (Mariedal formation) are exposed in the Fyleverken Sand Pit, Fyledal at Eriksdal (Figs 1, 2). The sediments are part of a $400-600 \mathrm{~m}$ thick succession that was deposited close to the boundary between the Vomb Trough and the Palaeozoic Colonus Trough (Fig. 9). Two coal samples from the lower part of the Fuglunda Member show reflectance values of $0.38 \% \mathrm{R}_{\mathrm{o}}$ and 0.39 $\% \mathrm{R}_{\mathrm{o}}$ (Table 2), and $T_{\max }$ values of $427^{\circ} \mathrm{C}$ and $433^{\circ} \mathrm{C}$.

\section{Jurassic of the northern Øresund}

Knowledge of the Jurassic in the Helsingør-Helsingborg area is derived from sea cliff and quarry exposures, from tunnel excavations, and from cored shallow wells in the Øresund and Skåne (Fig. 1). The deposits belong to the fault- and flexure-bounded Höganäs Basin within the Sorgenfrei-Tornquist Zone (Fig. 9).

Hettangian-Sinemurian sediments occur in the Øresund-13 and -18 wells. A coal seam in the former well yielded a reflectance of $0.46 \% \mathrm{R}_{\mathrm{o}}$, whereas a coal seam in the latter well yielded a reflectance of $0.51 \% \mathrm{R}_{\mathrm{o}}$ (Table 2). A Sinemurian coal seam in the Øresund-15 well has a reflectance of $0.36 \% \mathrm{R}_{\mathrm{o}}$ (Table 2 ). The relatively low reflectance value of the seam from the Øresund-15 well may be suppressed, as the pronounced content of huminite and the presence of pyrite indicate

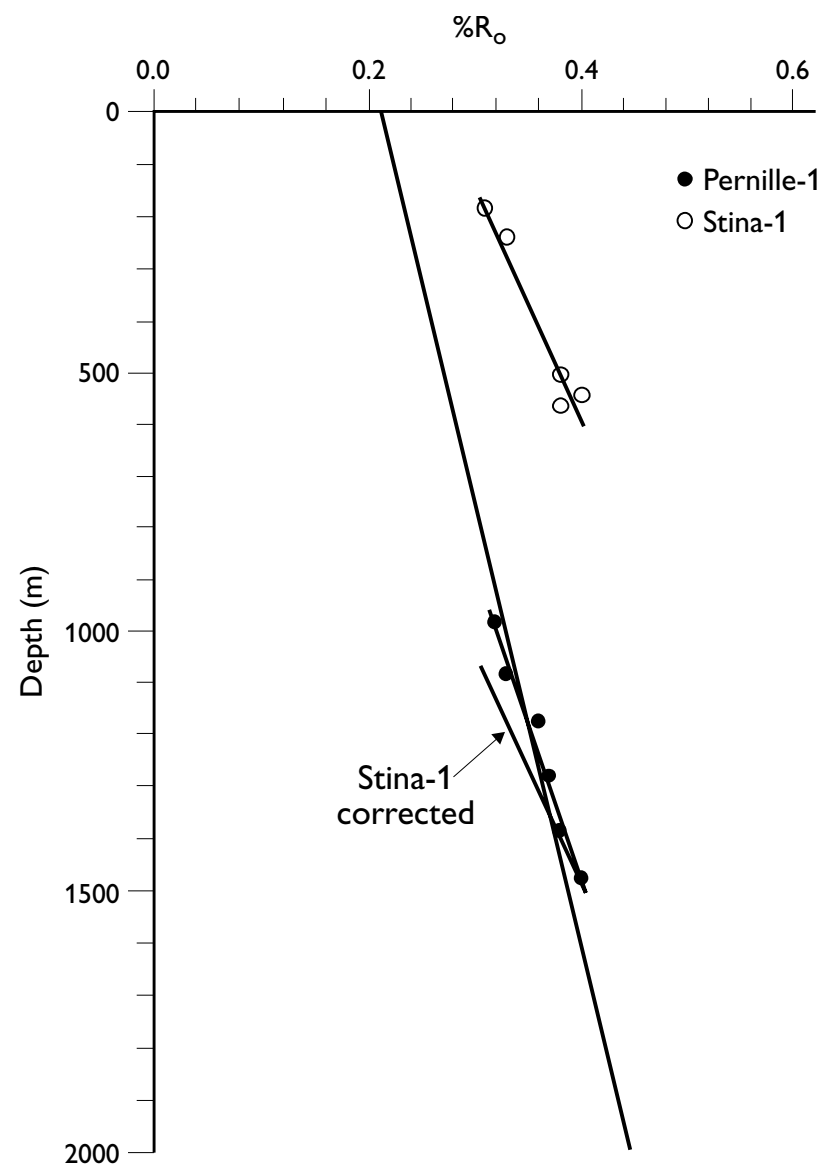

Fig. 8. Coalification profiles for the Lower Jurassic in the Pernille-1 well in the Rønne Graben and the Stina-1 well in the Kolobrzeg Graben. The regional coalification profile for the Danish Basin/ Skagerrak-Kattegat Platform is also shown. The profile from Pernille-1 falls on the regional trend indicating that the section has not been uplifted. The Stina-1 section has been uplifted c. $900 \mathrm{~m}$.

Fig. 9. Structural map of Skåne showing the present distribution of Rhaetian and Jurassic deposits. Modified from Norling \& Bergström (1987).

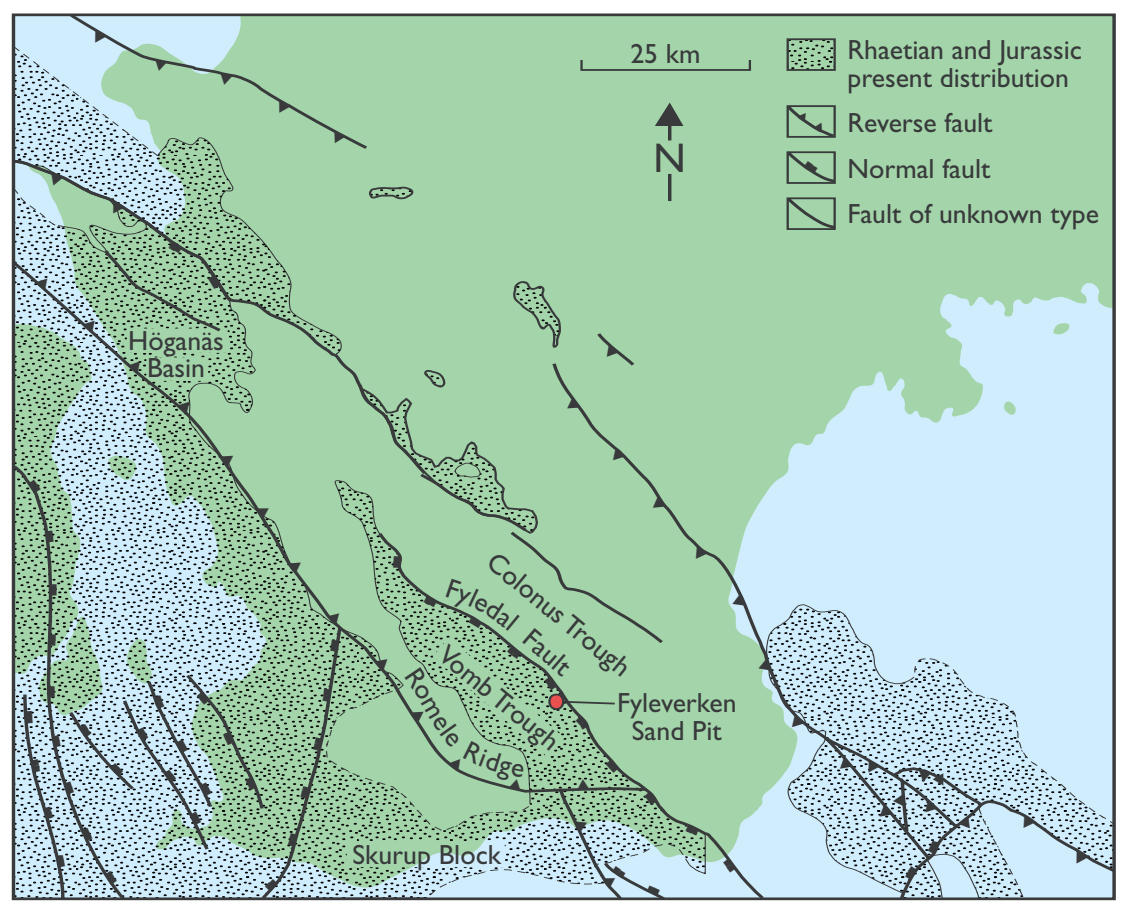


that anoxic and possibly occasional saline conditions were present in the precursor mire. This may have resulted in the formation of hydrogen-enriched huminite, which matures at a lower rate (Petersen \& Rosenberg 1998). The $T_{\max }$ is also low $\left(419^{\circ} \mathrm{C}\right)$. The $T_{\max }$ value of the coal from the Øresund -13 well is $426^{\circ} \mathrm{C}$ and the values from the $\varnothing$ resund -18 well are $424-428^{\circ} \mathrm{C}$. The $\mathrm{C}_{31}$-homohopane $22 \mathrm{~S} /(22 \mathrm{~S}+22 \mathrm{R})$ epimerisation ratio is 0.23 for the Øresund-13 well, whereas the ratio is in the range $0.37-0.42$ for the $\varnothing$ resund-18 well. Together with the reflectance values, these data are consistent with a higher rank of the coals from the Øresund-18 well compared to the coal from the Øresund-13 well.

The Bajocian-Bathonian coal from the Øresund-5 well has a reflectance of $0.39 \% \mathrm{R}_{\mathrm{o}}$, and the coals from the $\varnothing$ resund-7 well have reflectances in the range $0.41-0.46 \% \mathrm{R}_{\mathrm{o}}$, averaging $0.43 \% \mathrm{R}_{\mathrm{o}}$ (Table 2 ). Relative proportions of the thermally unstable hopenes and $\mathrm{B} \Omega$ forms are high in the Øresund-7 coals, and the $\mathrm{C}_{31}{ }^{-}$ homohopane $22 \mathrm{~S} /(22 \mathrm{~S}+22 \mathrm{R})$ epimerisation ratios are low (0.05-0.09). The average $T_{\max }$ value and the hopane ratios are similar to the values obtained from the Upper Pliensbachian - Lower Toarcian (Sorthat Formation) coal seams in the Levka-1 well on Bornholm. However, the reflectance values of the coal seams from the Øresund-7 well are higher, possibly due to increased oxidation during the humification process in the early stages of biochemical gelification (Diessel 1992; Hao \& Chen 1992).

Lower-Middle Jurassic Fjerritslev and Haldager Sand Formations, Kattegat

Approximately $200 \mathrm{~m}$ of Lower and Middle Jurassic deposits of the Fjerritslev and Haldager Sand Formations overlain by c. $100 \mathrm{~m}$ of Quaternary deposits were cored by a shallow well on the island of Anholt located in the Kattegat (Figs 1, 2). Reflectance measurements by Nielsen et al. (2003, this volume) give an average value of 0.33 $\% \mathrm{R}_{\mathrm{o}}$ (Table 2).

\section{Estimation of burial depths and later uplift}

The average reflectance values of the coals and the constructed regional coalification curve are used to estimate the maximum burial depth of the coal-bearing Lower and Middle Jurassic strata in the Fennoscandian Border Zone. The amount of later uplift equals the maximum burial depth in most cases as the majority of the samples were collected close to present sea level.

\section{Bornholm}

A burial depth of $c .1660 \mathrm{~m}$ is suggested for the outcropping coals of the Hettangian Munkerup Member, whereas the data from the overlying Hettangian to Sinemurian Sose Bugt Member (both of the Rønne Formation) indicate only c. $625 \mathrm{~m}$ of burial (Fig. 10; Table 2). The thickness of the non-exposed section between the seams in the Munkerup Member and those in the Sose Bugt Member is less than a few tens of metres (Gry 1969; Gravesen et al. 1982); a difference of approximately $1000 \mathrm{~m}$ in estimated burial depth between the seams is therefore impossible. The reflectance values from the Munkerup Member are considered to be too high, possibly due to hydrothermal influence; this aspect is discussed further below. The Sose Bugt Member in the Arnager-Sose Fault Block is overlain by at least $60 \mathrm{~m}$ of sediments assigned to the Hasle Formation (Gravesen et al. 1982; Surlyk et al. 1995), which in turn are unconformably overlain by Lower Cretaceous sediments. The base of the Lower Cretaceous was buried to c. $290 \mathrm{~m}$ followed by a similar amount of uplift (Petersen et al. 1996). This suggests that part of the uplift experienced by the Sose Bugt Member was related to the Middle Jurassic uplift event, which influenced the areas outside the Sorgenfrei-Tornquist Zone (Andsbjerg et al. 2001; Nielsen 2003, this volume), and only c. $290 \mathrm{~m}$ of the total uplift was caused by post-Early Cretaceous uplift.

The coal seams of the Sinemurian Galgeløkke Member exposed at the Galgeløkke coastal cliff have been buried to $c .1400 \mathrm{~m}$ with a later uplift of the same magnitude (Fig. 10; Table 2). The Hettangian coal seam at a depth of $383 \mathrm{~m}$ in the nearby Galgeløkke-2 well was buried to $c .1700 \mathrm{~m}$, corresponding to a burial depth for the base of the Jurassic of $c .1750-1775 \mathrm{~m}$ with a later uplift of c. $1320 \mathrm{~m}$. The difference in estimated burial depths of the two seams is thus $c .300 \mathrm{~m}$ which corresponds reasonably well with the estimated thickness of $c .400 \mathrm{~m}$ of the intervening strata.

The coal seams in the Upper Pliensbachian - Lower Toarcian part of the Sorthat Formation have been buried to c. $1210 \mathrm{~m}$ (Fig. 10; Table 2). The difference between the estimated burial depths of the seam from the Galgeløkke coastal cliff and the seams from the Levka-1 and Korsodde sections is c. $200 \mathrm{~m}$ which conforms well with an estimated thickness of 225-290 m of intervening strata. However, it should be noted that the estimated burial depth of the Levka-1 and Korsodde coals may be an under-estimate as the reflectance values of the coals may be slightly suppressed (Petersen et al. 2003, this volume). 
Fig. 10. The standard coalification curve for the Danish Basin/Skagerrak-Kattegat Platform used to estimate the burial depth of Lower and Middle Jurassic coalbearing strata from the islands of Anholt and Bornholm, the Øresund area and Skåne by means of huminite reflectance values.

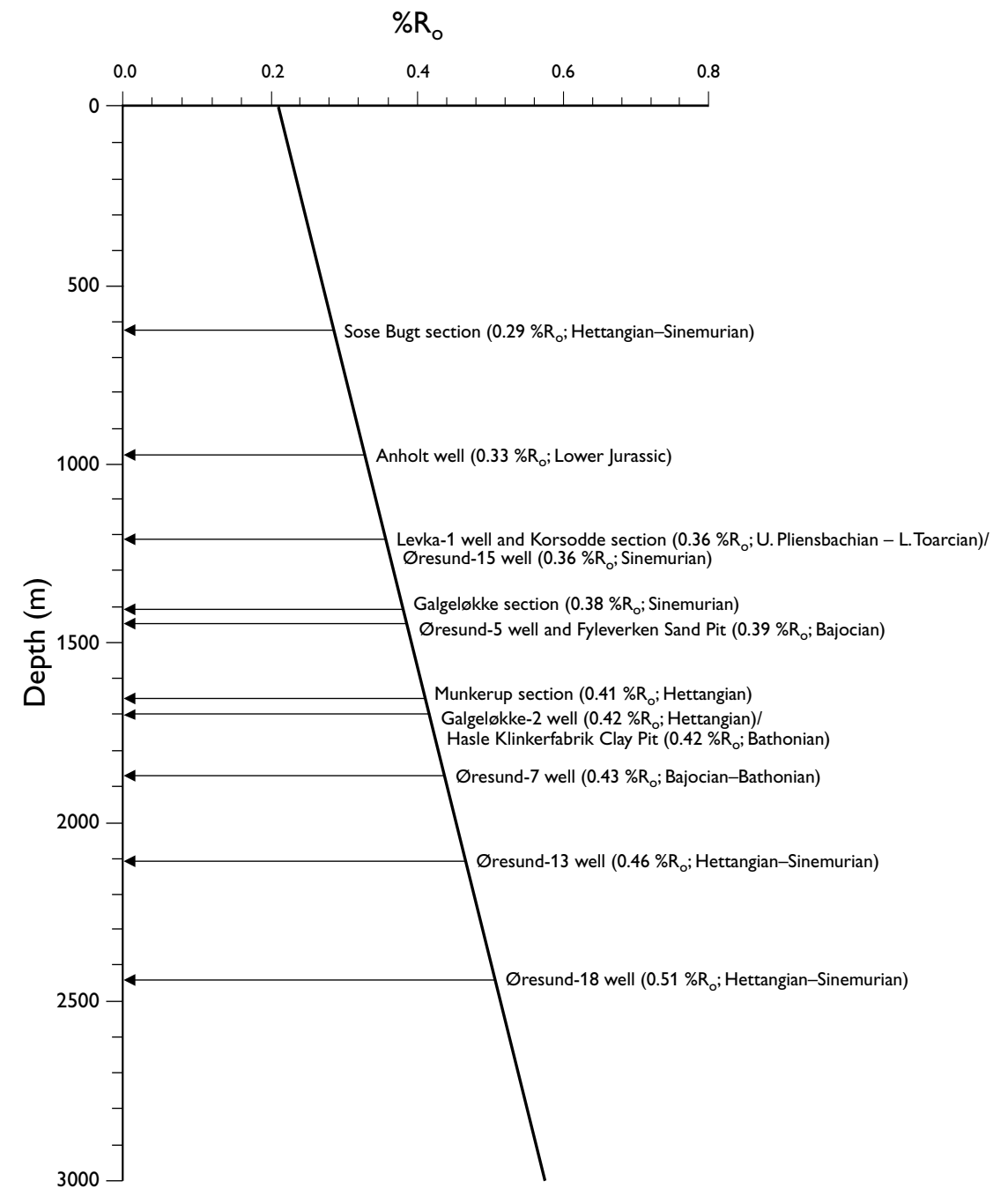

The data from the Bathonian coal seams in the uppermost Bagå Formation indicate a burial depth of $c$. $1700 \mathrm{~m}$ (Fig. 10; Table 2). This corresponds to $c .800 \mathrm{~m}$ deeper burial than the Levka-1 and Korsodde sections, and is unrealistic considering the structural and stratigraphic development of the two localities (Gry 1969; Gravesen et al. 1982; Jensen \& Hamann 1989). Hence, it is likely that the high reflectance values of the coals in the upper part of the Baga Formation were caused by an additional factor linked to the proximity of the major Rønne-Hasle Fault as discussed below.

These estimates suggest that the base of the Jurassic in the Rønne-Hasle Block at Galgeløkke-2 was buried to $c .1750-1775 \mathrm{~m}$ and later uplifted $c .1320 \mathrm{~m}$. This is consistent with the seismic interpretation by Hamann (1994) indicating up to $1400 \mathrm{~m}$ of inversion along the Rønne-Hasle Fault. The maximum burial depth of $1750-1775 \mathrm{~m}$ is compatible with the likely cumulative thicknesses of the Jurassic-Cretaceous section in the Rønne-Hasle Block. In Pernille-1, for instance, the Jurassic-Cretaceous section has a minimum thickness of c. $1450 \mathrm{~m}$, comprising c. $600 \mathrm{~m}$ of Lower Jurassic deposits overlain by c. $850 \mathrm{~m}$ of probable Lower to Upper Cretaceous deposits. In the Rønne-Hasle Block, the cumulative thickness may have been up to $2000 \mathrm{~m}$, as c. $1000 \mathrm{~m}$ of Jurassic deposits are preserved, and the original thickness of the Cretaceous succession may have been up to $c .1000 \mathrm{~m}$, as suggested by reference to the adjacent Nyker Block and Pernille-1.

\section{Rønne and Kolobrzeg Grabens}

The reflectance values of the Rønne Formation in Pernille- 1 plot on the trend of the coalification curve (Fig. 8). Thus the present depth of the Jurassic deposits corresponds to the maximum burial depth. This contrasts with the interpretation of a seismic section through the Pernille-1 well indicating c. $270 \mathrm{msec}(c .400 \mathrm{~m})$ of inversion relative to the stable Skurup Block (Fig. 11).

The data from the Stina-1 section situated in the Kolobrzeg Graben suggest a burial depth of $c .1500 \mathrm{~m}$ for the base of the Jurassic and c. $900 \mathrm{~m}$ of later uplift (Figs 7,8). Seismic interpretation suggests a similar 


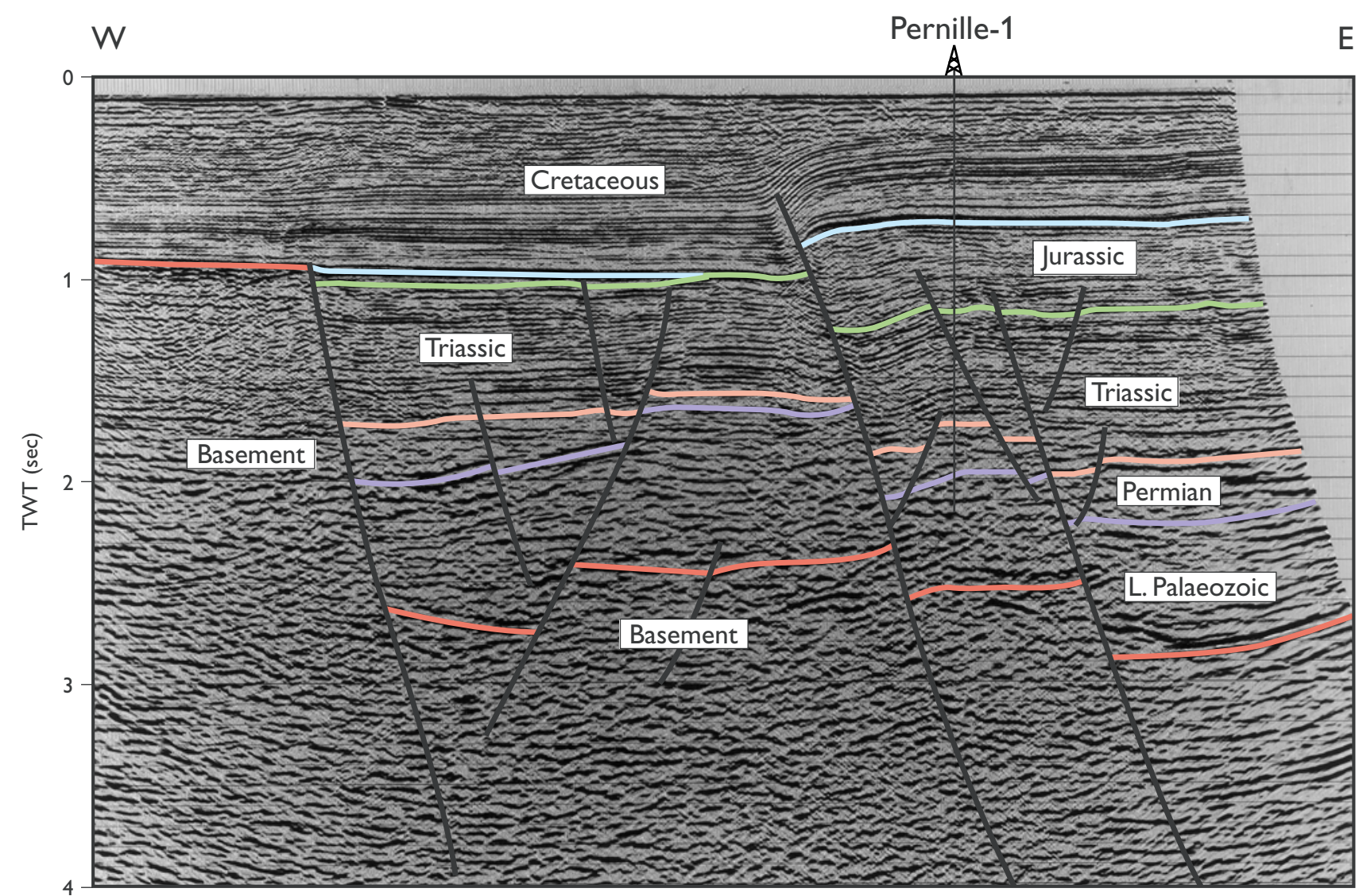

Fig. 11. Interpreted seismic section through the Pernille-1 well showing c. $270 \mathrm{msec}$ of inversion corresponding to $c$. $400 \mathrm{~m}$ (interval velocity $=2942 \mathrm{~m} / \mathrm{sec}$; Nielsen \& Japsen 1992). Slightly modified from Vejbæk et al. (1994).

amount of uplift during the inversion phase (Hamann 1994; Vejbæk et al. 1994). Stina-1 is located close to the section shown in Figure 12B, which indicates inversion of 1000-1100 m within the Kolobrzeg Graben. Evidence of inversion is also prominent on a SW-NE section east of Bornholm (Fig. 12C).

The Lower Jurassic strata in the Pernille- 1 and Stina-1 wells were buried to the same depth in the two areas prior to uplift at Stina-1. The Lower Jurassic is unconformably overlain by Quaternary deposits in Stina-1, whereas the Lower Jurassic is overlain by c. $850 \mathrm{~m}$ of Upper Cretaceous deposits in Pernille-1; this is consistent with the estimate of $c .900 \mathrm{~m}$ of uplift at Stina-1.

\section{Fyleverken Sand Pit, Fyledal, Skåne}

The reflectance values of the Bajocian coals from Fyledal suggest a burial depth of $c .1450 \mathrm{~m}$ in the Eriksdal area and a similar amount of later uplift (Fig. 10; Table 2). In the Vomb Trough, crystalline basement is overlain by up to $200 \mathrm{~m}$ of Jurassic - Lower Cretaceous strata and c. $1000 \mathrm{~m}$ of Upper Cretaceous deposits, but much of the Santonian-Campanian succession accumulated con- temporaneously with the inversion of the SorgenfreiTornquist Zone (Erlström \& Guy-Ohlson 1994). The thickness of the Santonian-Campanian succession thus reflects the relative fault movements and not directly the uplift. In the Fyleverken Sand Pit section in Fyledal, the post-Bajocian Jurassic section is $c .400 \mathrm{~m}$ thick, and the Lower Cretaceous - Turonian section was probably c. $200 \mathrm{~m}$ thick before tilting during Santonian-Campanian inversion (Norling \& Bergström 1987). Erlström (1994) suggested that c. $300 \mathrm{~m}$ of Maastrichtian deposits were eroded during Neogene uplift. The Jurassic-Cretaceous succession may thus have been $c .900 \mathrm{~m}$ thick. Paleocene and Eocene deposits seem to be confined to the basin south-west of the Helsingborg-Romele Fault. However, Cenozoic deposits may have covered eastern Skåne and are thought to be present in the Hanö Bay area (Lidmar-Bergström 1982; Norling \& Bergström 1987). It is thus very difficult to evaluate in detail the thickness of strata that has been removed on the basis of the preserved stratigraphy, and to support the burial estimate of c. $1450 \mathrm{~m}$. In addition, hydrothermal influence on the rank cannot be precluded (see below). The amount of inversion in the north-western part of the Sorgenfrei- Tornquist Zone is typically suggested to 

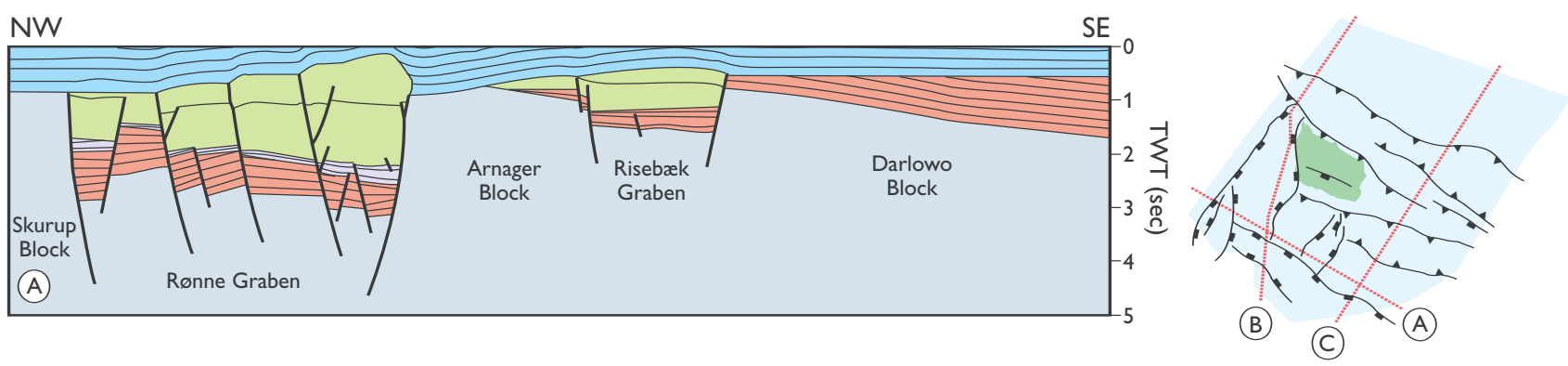

SW
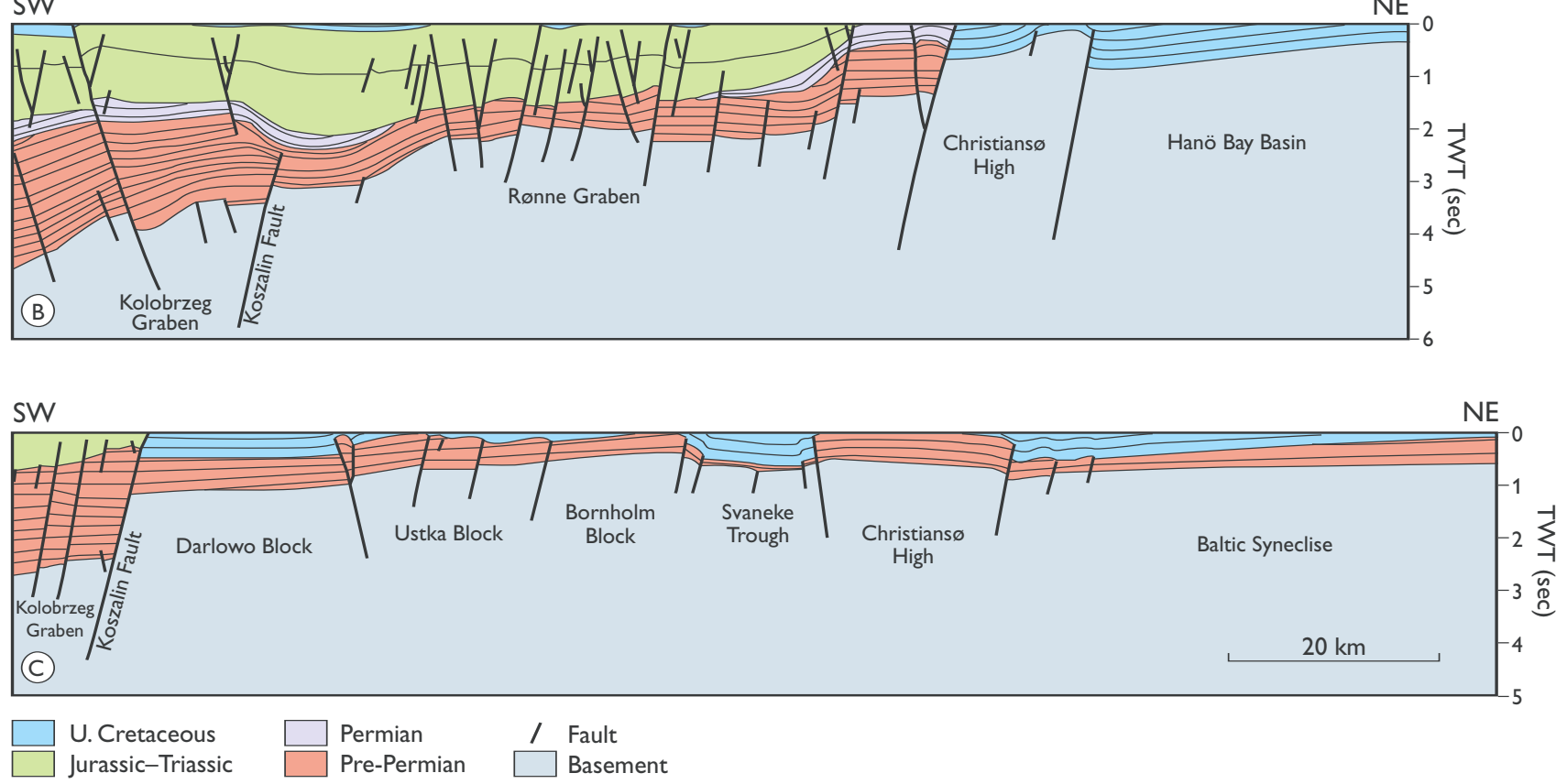

Fig. 12. Geosections around Bornholm (see inset map) with depths in two-way travel time (TWT), based on interpreted seismic sections. A: Note the lack of significant inversion relative to the Skurup Platform at the western margin of the Rønne Graben in contrast to the marked inversion relative to the Arnager Block in the south-eastern part of the graben. B: Note the very significant inversion of the Kolobrzeg Graben relative to the Hanö Bay Basin. Stina-1 is located in the Kolobrzeg Graben close to the Koszalin Fault. C: Inversion of the Kolobrzeg Graben is also evident on the SW-NE section, east of Bornholm. Slightly modified from Vejbæk et al. (1994).

be up to 1000 m (Jensen \& Michelsen 1992; Japsen 1993; Michelsen \& Nielsen 1993). Extension of the regional trend of Neogene uplift shown by Jensen \& Michelsen (1992) and Japsen (1993) into Skåne may suggest $1000-1500 \mathrm{~m}$ of uplift in this area. However, this trend is mainly based on data to the north-west of Skåne and thus may not be directly applicable.

\section{Northern Øresund}

In the Höganäs Basin, the data from the HettangianSinemurian coal seams in the Øresund- 13 and -18 wells indicate burial depths of $c .2100 \mathrm{~m}$ and $2440 \mathrm{~m}$ respectively (Figs 1, 9, 10; Table 2). Uplift in the Øresund area was evaluated by modelling of a pseudo-well, based on a stratigraphic reconstruction from the shallow wells
(Fig. 13) and the stratigraphic information given in plate 21 of Larsen et al. (1968). The modelling shows that the differences in reflectance $\left(\% \mathrm{R}_{\mathrm{o}}\right)$ can be explained by the thickness of the intervening strata with the exception of the Øresund-15 well. The low value obtained from this well may be due to suppression, as mentioned earlier. The basin modelling indicates an uplift of $1200 \mathrm{~m}$ for the Øresund-1 well location, corresponding to uplift of $2100 \mathrm{~m}$ at the Øresund-13 well location and $2550 \mathrm{~m}$ at the Øresund-18 well location. This is in close agreement with the values determined from the coalification curve and is compatible with the stratigraphy (Fig. 13; Larsen et al. 1968, plate 21).

Reflectance values of three Hettangian coal samples from the nearby Helsingborg railway tunnel range from $0.48 \% \mathrm{R}_{\mathrm{o}}$ to $0.57 \% \mathrm{R}_{\mathrm{o}}$, and dispersed huminite from Hettangian deposits in the nearby Ramlösa-1b well gives 
(A)

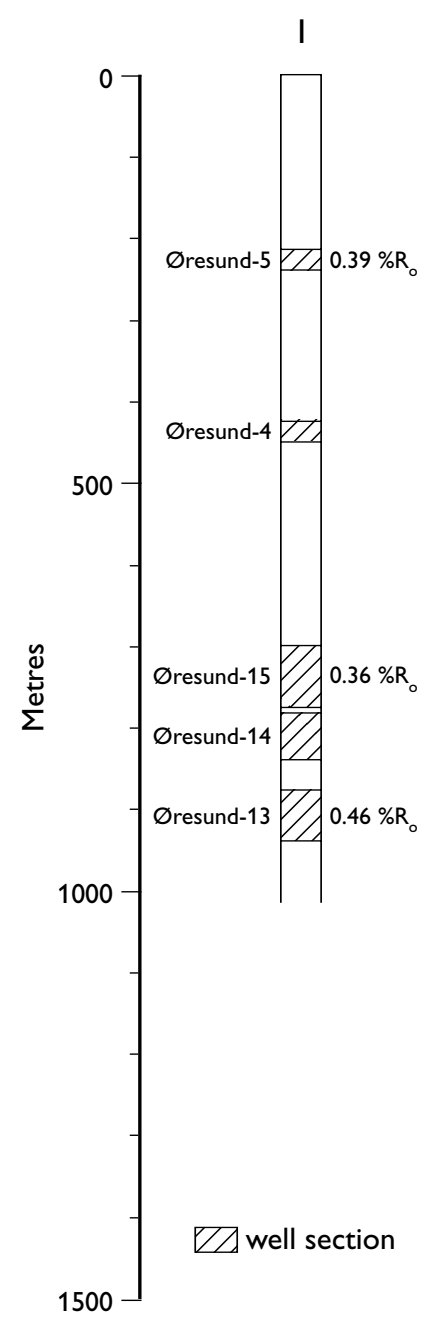

(B)

II

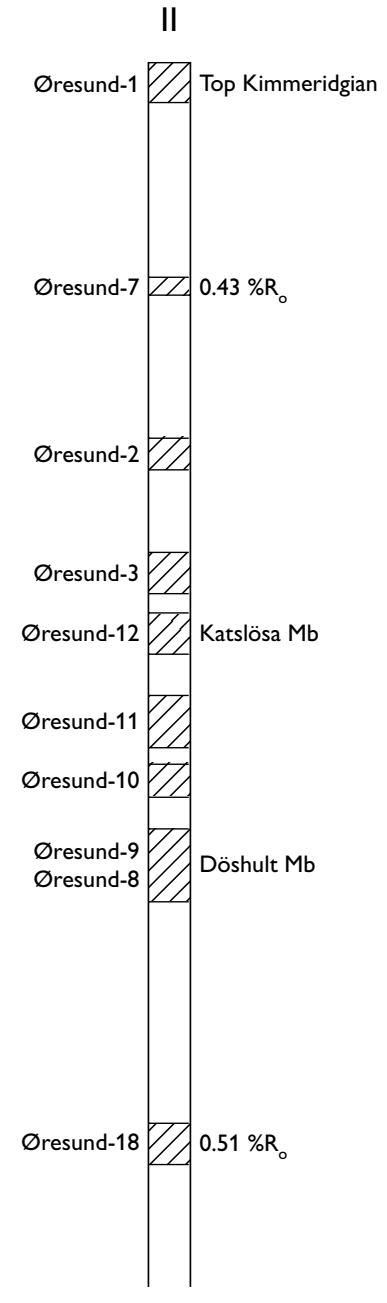

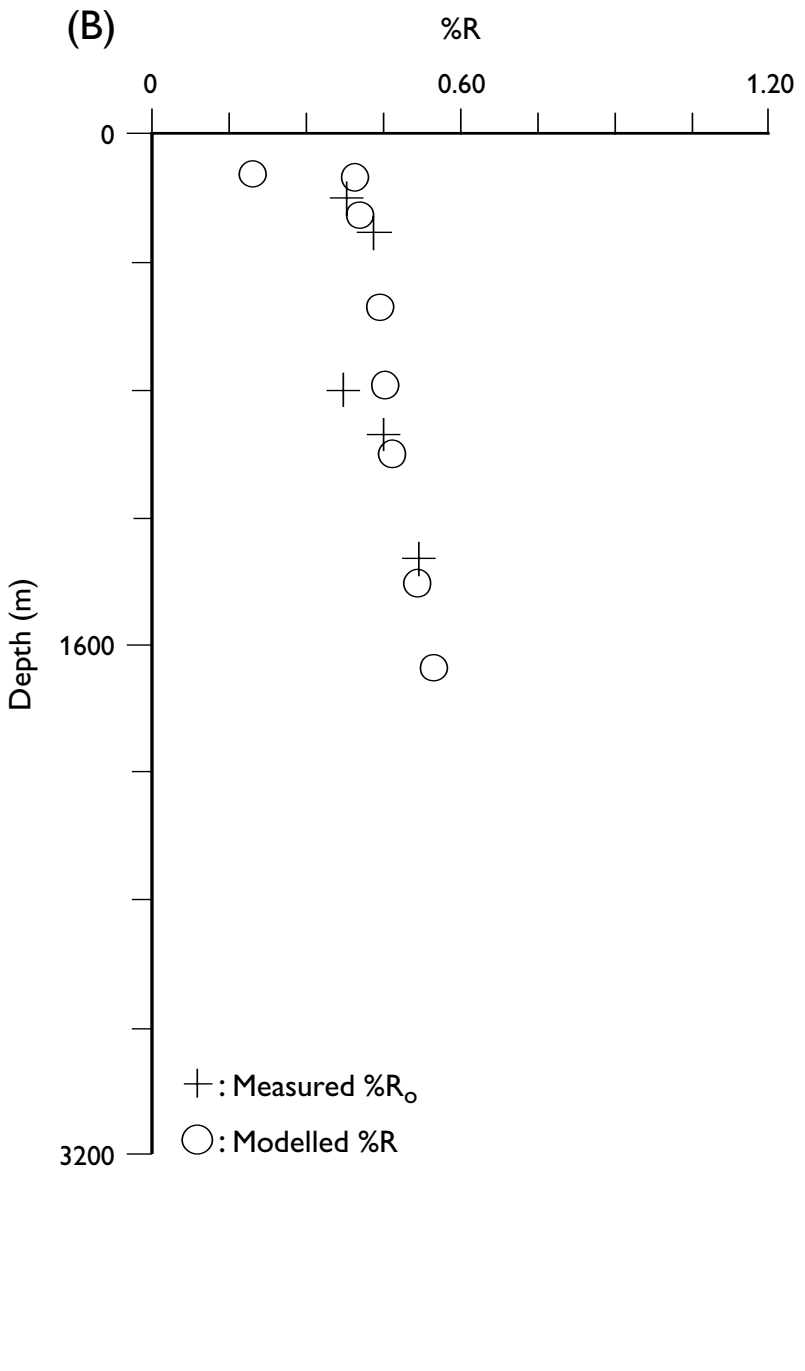

Fig. 13. A: Reconstructed stratigraphic columns at the location of the Øresund-1 well. The reconstructions are based on the geological profiles along the tunnel transect (column I) and the bridge transect (column II) shown on plate 21 in Larsen et al. (1968). B: Modelled reflectance values from the constructed pseudo-well compared to measured values.

a value of $0.48 \% \mathrm{R}_{\mathrm{o}}$ (Ahlberg 1994). These data suggest burial depths between $2250 \mathrm{~m}$ and $3050 \mathrm{~m}$.

The Bajocian-Bathonian coal seams in the Øresund-5 and Øresund-7 wells situated immediately west of the inversion zone, were buried and later uplifted c. $1450 \mathrm{~m}$ and c. $1875 \mathrm{~m}$, respectively, corresponding to modelled values of $c .1400 \mathrm{~m}$ for the Øresund- 5 well and c. $1500 \mathrm{~m}$ for the Øresund-7 well (Figs 10, 13; Table 2).

\section{Anholt well, Kattegat}

The Lower-Middle Jurassic strata encountered in the Anholt well were buried and uplifted c. 975 m (Fig. 10; Table 2). The island of Anholt is located on the bound- ary between the Skagerrak-Kattegat Platform and the inversion zone. The uplift is mainly interpreted as being of Neogene-Pleistocene age, and the degree of uplift is slightly less than that inferred for the Sæby-1 well (Japsen 1993; Michelsen \& Nielsen 1993). Approximately $1000 \mathrm{~m}$ of uplift was estimated by Nielsen et al. (2003, this volume) based on the same reflectance data but utilising a general North Sea coalification curve.

\section{Hydrothermal influence on the maturation of organic matter}

The vast majority of the reflectance values provide reasonable estimates of burial depths that are consistent 
with stratigraphic thicknesses and other evidence of burial depths. However, the rank of the coals from the Munkerup Member, the uppermost Bagå Formation, and possibly the Fuglunda Member appear anomalously high. A mechanism other than thermal influence with burial depth is needed to explain these anomalies.

The precursor peats of the uppermost Bagå Formation coals were formed in a relatively well-aerated environment, which may have produced hydrogen-poor and oxygen-rich huminite precursor material that matured at an enhanced rate (Hao \& Chen 1992). However, this explanation cannot be applied to the coals of the Munkerup Member, and may not be sufficient to explain the large difference in reflectance between the coals from the Sorthat and Baga Formations on Bornholm. Therefore, it is proposed that the elevated maturity was the result of a local rise in temperature due to hydrothermal activity.

Hydrothermal processes associated with fault movements have been proposed to explain the occurrence of sideritic iron ores and copper mineralisation along the Fyledal Fault Zone and zeolites in Campanian deposits in the Vomb Trough (Norling \& Bergström 1987; Erlström 1994). Middle Jurassic volcanic activity occurred in Skåne along fault and fracture zones, and hot brines influenced the diagenesis of Rhaetian and Lower Jurassic sandstones and caused anomalously high vitrinite reflectances (Klingspor 1976; Norling \& Bergström 1987; Ahlberg 1994; Ahlberg \& Goldstein 1994). The silica-cemented Höör Sandstone (a lateral equivalent of the Höganäs Formation, Fig. 2), which has not been buried more than a few hundred metres, was indurated at temperatures from $100-200^{\circ} \mathrm{C}$, and the organic matter shows reflectance values that locally reach $0.9 \% \mathrm{R}_{\mathrm{o}}$ corresponding to a burial depth of $c .5700 \mathrm{~m}$. Bottomhole temperatures in the Hans-1 well in the Kattegat were high in Lower Jurassic strata at very shallow depths $\left(45^{\circ} \mathrm{C}\right.$ at $\left.316 \mathrm{~m}\right)$ whereas normal temperatures were recorded at deeper levels. The real temperature of the Jurassic deposits is even higher than indicated by the borehole measurement, because of the cooling effect of the drilling mud. The occurrence of hydrothermal activity along faults and the effect on the diagenesis of organic as well as siliciclastic deposits is thus well-documented. Some of the observed anomalies in the Jurassic coals may therefore be related to the Middle Jurassic volcanic activity in Skåne.

The uppermost Bagå Formation coals are situated close to the fault that separates the Rønne Graben from the crystalline basement of the Bornholm High, and it is possible that hot formation waters expelled from deeply buried deposits percolated upwards along the fault and into the coal-bearing strata. The occurrence of abundant epigenetic pyrite in the coals and large pyrite nodules in sand interbeds lend support to this interpretation, as the most likely source of the sulphur is saline formation water from older sediments containing salt and gypsum (Petersen et al. 2003, this volume). A similar situation has been reported from the Carboniferous St. Rose and Chimney Corner coalfields in Nova Scotia, Canada (Beaton et al. 1993).

The Munkerup Member coals occur close to the northern and eastern bounding faults of the ArnagerSose Fault Block, and these faults may also have functioned as conduits for hot formation waters, thus explaining the high rank of the coals.

\section{Discussion and conclusions}

A well-constrained, uplift-corrected coalification curve has been constructed from reflectance data representing a wide range of burial depths of the Upper Triassic - Lower Cretaceous succession in the Danish Basin and the Fennoscandian Border Zone. We suggest that this curve may be used as a standard with which new data can be compared. The reflectance values from wells in the Fjerritslev Trough and the Terne- 1 well deviate from the main coalification trend. Basin modelling and velocity data from the Chalk Group (Japsen 1998) suggest that the uplift correction may be erroneous due to overestimation of the burial depth based on Fjerritslev Formation sonic velocities in these wells. These data have thus not been incorporated in the standard curve.

Average reflectance values from the Lower-Middle Jurassic coals in the Fennoscandian Border Zone range from $0.29 \% \mathrm{R}_{\mathrm{o}}$ to $0.51 \% \mathrm{R}_{\mathrm{o}}$ (Table 2 ), which are compatible with low rank coals, and directly indicate relatively shallow burial depths. The use of the regional curve to assess the burial depths and later uplift of coalbearing Lower-Middle Jurassic strata in the Fennoscandian Border Zone has provided reliable and consistent results (Table 2). Hydrothermal activity related to the Middle Jurassic volcanic event may locally have influenced the maturation of the coals in the Hettangian-Sinemurian of the Höganäs Basin, and possibly the coals in the Fuglunda Member at Fyledal. The rank of the coals in the Munkerup Member (Rønne Formation) and uppermost Bagå Formation on Bornholm was probably raised by hot formation waters expelled from deeply buried layers. 
The reflectance data indicate $c$. $900-1400 \mathrm{~m}$ of postEarly Cretaceous uplift of the Jurassic succession in the Rønne-Hasle Fault Block and the Kolobrzeg Graben (Table 2). This degree of uplift is compatible with the amount of Late Cretaceous - Early Cenozoic inversion based on seismic interpretation (Hamann 1994; Vejbæk et al. 1994), and is similar to the 550-1000 m of inversion that has been interpreted from the SorgenfreiTornquist Zone further to the north-west (Japsen 1993; Michelsen \& Nielsen 1993). Thus the total post-Early Cretaceous uplift in the Bornholm area determined from reflectance values can be explained by inversion alone, without the need for significant Neogene-Pleistocene uplift. The data from the Arnager-Sose Fault Block indicate Early Jurassic burial of $625 \mathrm{~m}$ followed by a similar magnitude of Middle-Late Jurassic uplift and erosion. Post-Early Cretaceous uplift only amounts to $290 \mathrm{~m}$.

The estimated uplift of the Jurassic section in the Höganäs Basin, reflecting both inversion and NeogenePleistocene uplift, is a minimum of $2010 \mathrm{~m}$ (Table 2). This is similar to the total uplift of $1730-2000 \mathrm{~m}$ of the Hans-1 well-section in the Kattegat (Japsen 1993; Michelsen \& Nielsen 1993). The $c .1450-1875 \mathrm{~m}$ of uplift indicated by the Øresund- 5 and -7 data is a function of both Neogene uplift and drag along the inversion zone. The rank of the Bajocian Fuglunda Member coal bed suggests c. $1450 \mathrm{~m}$ of total uplift, which appears to be a reasonable estimate based on the likely overburden and regional evidence, but it cannot be precluded that the rank has been increased due to hydrothermal influence. The total uplift of the Anholt well-section is estimated to be $c .975 \mathrm{~m}$, rather than the $>1200 \mathrm{~m}$ suggested by Jensen \& Michelsen (1992) but in agreement with the c. $1000 \mathrm{~m}$ of Nielsen et al. (2003, this volume). The data from Anholt and Bornholm may suggest that the amount of Neogene-Pleistocene uplift in Skåne was relatively small compared to the northern part of the Danish Basin and the Fennoscandian Border Zone, but further data are needed for confirmation.

\section{Acknowledgements}

Ole V. Vejbæk and Peter Japsen are thanked for discussions, Jørgen A. Bojesen-Koefoed kindly assisted with data plotting, and Niels-Erik Hamann generously allowed us to include an unpublished figure (Fig. 7). The referees, Lars N. Jensen and John E.A. Marshall, are thanked for their constructive comments.

\section{References}

Ahlberg, A. 1994: Diagenesis of Rhaetian-Hettangian coal-bearing siliciclastic strata in NW Skåne, southern Sweden. In: Ahlberg, A.: Deposition and diagenesis of the RhaetianHettangian succession (Triassic-Jurassic) in southern Sweden, 53 pp. Unpublished Ph.D. thesis, Lund University, Sweden.

Ahlberg, A. \& Goldstein, R.H. 1994: Fluid inclusions in quartz overgrowths: evidence of mid-Jurassic volcanic hot brine flushing at shallow burial depth in the Lower Jurassic Höör Sandstone, southern Sweden. In: Ahlberg, A.: Deposition and diagenesis of the Rhaetian-Hettangian succession (Triassic-Jurassic) in southern Sweden, 53 pp. Unpublished Ph.D. thesis, Lund University, Sweden.

Ahlberg, A., Sivhed, U. \& Erlström, M. 2003: The Jurassic of Skåne, southern Sweden. In: Ineson, J.R. \& Surlyk, F. (eds): The Jurassic of Denmark and Greenland. Geological Survey of Denmark and Greenland Bulletin 1, 527-541 (this volume).

Andsbjerg, J., Nielsen, L.H., Johannessen, P.N. \& Dybkjær, K. 2001: Divergent development of two neighbouring basins following the Jurassic North Sea doming event: the Danish Central Graben and the Norwegian-Danish Basin. In: Martinsen, O.J. \& Dreyer, T. (eds): Sedimentary environments offshore Norway - Palaeozoic to Recent. Norwegian Petroleum Society (NPF) Special Publication 10, 175-197.

Balling, N. 1995: Heat flow and thermal structure of the lithosphere across the Baltic Shield and northern Tornquist Zone. Tectonophysics 244, 13-50.

Beaton, A.P., Kalkreuth, W. \& MacNeil, D. 1993: The geology, petrology and geochemistry of coal seams from the St. Rose and Chimney Corner coalfields, Cape Breton, Nova Scotia, Canada. International Journal of Coal Geology 24, 47-73.

Bertelsen, F. 1980: Lithostratigraphy and depositional history of the Danish Triassic. Danmarks Geologiske Unders $\varnothing$ gelse Serie B 4, 59 pp.

Bray, E.E. \& Evans, E.D. 1961: Distribution of $n$-paraffins as a clue to recognition of source beds. Geochimica et Cosmochimica Acta 22, 2-15.

Carr, A.D. \& Williamson, J.E. 1990: The relationship between aromaticity, vitrinite reflectance and maceral composition of coals: implications for the use of vitrinite reflectance as a maturation parameter. Organic Geochemistry 16, 313-323.

Christensen, J.E. \& Korstgård, A.J. 1994: The Fjerritslev Fault offshore Denmark - salt and fault interactions. First Break 2, 31-42.

Cooper, J.E. \& Bray, E.E. 1963: A postulated role of fatty acids in petroleum formation. Geochimica et Cosmochimica Acta 27, $1113-1127$.

Damberger, H. 1968: Ein Nachweis der Abhängigkeit der Inkohlung von der Temperatur. Brennstoff-Chemie 49, 73-77.

Diessel, C.F.K. 1992: Coal-bearing depositional systems, 721 pp. Berlin Heidelberg: Springer Verlag.

Dow, W.G. 1977: Kerogen studies and geological interpretations. Journal of Geochemical Exploration 7, 79-99.

Erlström, M. 1994: Evolution of Cretaceous sedimentation in Scania. Lund Publications in Geology 122, 37 pp.

Erlström, M. \& Guy-Ohlson, D. 1994: Campanian depositional settings in the Vomb Trough, Scania, Sweden. Geologiska 
Föreningens i Stockholm Förhandlingar 116, 193-202.

EUGENO-S Working Group 1988: Crustal structure and tectonic evolution of the transition between the Baltic Shield and the North German Caledonides. Tectonophysics 150, 253-348.

Forchhammer, J.G. 1835: Danmarks geognostiske forhold, 112 pp. København: Jens Hostrup Schulz.

Gravesen, P., Rolle, F. \& Surlyk, F. 1982: Lithostratigraphy and sedimentary evolution of the Triassic, Jurassic and Lower Cretaceous of Bornholm, Denmark. Danmarks Geologiske Undersøgelse Serie B 7, 51 pp.

Gry, H. 1969: Megaspores from the Jurassic of the island of Bornholm, Denmark. Meddelelser fra Dansk Geologisk Forening 19, 69-89.

Hamann, N.-E. 1994: Den tektoniske udvikling af Rønne Graven - et seismisk studie, 136 pp. Unpublished Ph.D. thesis, University of Copenhagen, Copenhagen, Denmark.

Hao, F. \& Chen, J. 1992: The cause and mechanism of vitrinite reflectance anomalies. Journal of Petroleum Geology 15, 419-434.

Isaksen, G.H. 1995: Organic geochemistry of paleodepositional environments with predominance of terrigenous higher-plant organic matter. In: Huc, A.-Y. (ed.): Paleogeography, paleoclimate, and source rocks. American Association of Petroleum Geologists Studies in Geology 40, 81-104.

Japsen, P. 1993: Influence of lithology and Neogene uplift on seismic velocities in Denmark: Implications for depth conversion of maps. American Association of Petroleum Geologists Bulletin 77, 194-211.

Japsen, P. 1998: Regional velocity-depth anomalies, North Sea Chalk: a record of overpressure and Neogene uplift and erosion. American Association of Petroleum Geologists Bulletin 82, 2031-2074.

Jensen, J.B. \& Hamann, N.-E. 1989: Geological mapping of Mesozoic deposits along the eastern margin of the Rønne Graben, offshore Bornholm, Denmark. Bulletin of the Geological Society of Denmark 37, 237-260.

Jensen, L.N. \& Michelsen, O. 1992: Tertiær hævning og erosion i Skagerrak, Nordjylland og Kattegat. Dansk Geologisk Forening Årsskrift 1990-91, 159-168.

Jensen, L.N. \& Schmidt, B.J. 1992: Late Tertiary uplift and erosion in the Skagerrak area: magnitude and consequences. Norsk Geologisk Tidsskrift 72, 275-279.

Jensen, L.N. \& Schmidt, B.J. 1993: Neogene uplift and erosion offshore south Norway: magnitude and consequences for hydrocarbon exploration in the Farsund Basin. In: Spencer, A.M. (ed.): Generation, accumulation and production of Europe's hydrocarbons. III. European Association of Petroleum Geoscientists Special Publication 3, 79-88.

Klingspor, I. 1976: Radiometric age-determination of basalts, dolerites and related syenite in Skåne, southern Sweden. Geologiska Föreningens i Stockholm Förhandlingar 98, 195-216.

Koch, J.-O. 1983: Sedimentology of Middle and Upper Jurassic sandstone reservoirs of Denmark. Geologie en Mijnbouw 62, 115-129.

Koppelhus, E.B. \& Nielsen, L.H. 1994: Palynostratigraphy and palaeoenvironments of the Lower to Middle Jurassic Bagå
Formation of Bornholm, Denmark. Palynology 18, 139-194.

Larsen, G., Christensen, O.B., Bang, I. \& Buch, A. 1968: Øresund. Helsingør-Hälsingborg Linien. Geologisk rapport. Danmarks Geologiske Undersøgelse Rapport 1, 90 pp., + table volume (summary in English).

Liboriussen, J., Ashton, P. \& Tygesen, T. 1987: The tectonic evolution of the Fennoscandian Border Zone in Denmark. In: Ziegler, P.A. (ed.): Compressional intra-plate deformations in the Alpine Foreland. Tectonophysics 137, 21-29.

Lidmar-Bergström, K. 1982: Pre-Quaternary geomorphological evolution in southern Fennoscandia. Sveriges Geologiska Undersökning Serie C 785, 202 pp.

Manum, S.B. \& Throndsen, T. 1978: Rank of coal and dispersed organic matter and its geological bearing in the Spitsbergen Tertiary. Norsk Polarinstitutt Årbok 1977, 159-172.

Michelsen, O. 1978: Stratigraphy and distribution of Jurassic deposits of the Norwegian-Danish Basin. Danmarks Geologiske Undersøgelse Serie B 2, 28 pp.

Michelsen, O. \& Nielsen, L.H. 1991: Well records on the Phanerozoic stratigraphy in the Fennoscandian Border Zone, Denmark. Hans-1, Sæby-1, and Terne-1 wells. Danmarks Geologiske Undersøgelse Serie A 29, 37 pp.

Michelsen, O. \& Nielsen, L.H. 1993: Structural development of the Fennoscandian Border Zone, offshore Denmark. Marine and Petroleum Geology 10, 124-134.

Michelsen, O., Nielsen, L.H., Johannessen, P.N., Andsbjerg, J. \& Surlyk, F. 2003: Jurassic lithostratigraphy and stratigraphic development onshore and offshore Denmark. In: Ineson, J.R. \& Surlyk, F. (eds): The Jurassic of Denmark and Greenland. Geological Survey of Denmark and Greenland Bulletin 1, 147-216 (this volume).

Mogensen, T.E. 1994: Palaeozoic structural development along the Tornquist Zone, Kattegat area, Denmark. In: Cloetingh, S. et al. (eds): Dynamics of extensional basin formation and inversion. Tectonophysics 240, 191-214.

Nielsen, L.H. 1993: Øvre Trias - Mellem Jura aflejringerne i det Danske Bassin. Dansk Geologisk Forenings 100 års jubilæumssymposium - Geologi på tværs af det Danske Rige. Copenhagen, 19-20 November 1993. Abstracts, 35-38.

Nielsen, L.H. 1995: Genetic stratigraphy of the Upper Triassic Middle Jurassic deposits of the Danish Basin and Fennoscandian Border Zone 2, 3, 162 pp. Unpublished Ph.D. thesis, University of Copenhagen, Copenhagen, Denmark.

Nielsen, L.H. 2003: Late Triassic - Jurassic development of the Danish Basin and the Fennoscandian Border Zone, southern Scandinavia. In: Ineson, J.R. \& Surlyk, F. (eds): The Jurassic of Denmark and Greenland. Geological Survey of Denmark and Greenland Bulletin 1, 459-526 (this volume).

Nielsen, L.H. \& Japsen, P. 1992: Deep wells in Denmark 1935-1991. Confidential report. DGU Datadokumentation 1, 195 pp. København: Danmarks Geologiske Undersøgelse.

Nielsen, O.B., Seidenkrantz, M.-S., Abrahamsen, N., Schmidt, B.J., Koppelhus, E.B., Ravn-Sørensen, H., Korsbech, U. \& Nielsen, K.G. 2003: The Lower-Middle Jurassic of the Anholt borehole: implications for the geological evolution of the eastern margin of the Danish Basin. In: Ineson, J.R. \& Surlyk, F. (eds): The Jurassic of Denmark and Greenland. Geological Survey 
of Denmark and Greenland Bulletin 1, 585-609 (this volume).

Nielsen, S.B. \& Balling, N. 1990: Modelling subsidence, heat flow, and hydrocarbon generation in extensional basins. First Break 8, 23-31.

Norling, E. \& Bergström, J. 1987: Mesozoic and Cenozoic tectonic evolution of Scania, southern Sweden. In: Ziegler, P.A. (ed.): Compressional intra-plate deformations in the Alpine Foreland. Tectonophysics 137, 7-19.

Nyland, B., Jensen, L.N., Skagen, J., Skarpnes, O. \& Vorren, T. 1992: Tertiary uplift and erosion in the Barents Sea; magnitude, timing and consequences. In: Larsen, R.M., Larsen, B.T. \& Brekke, H. (eds): Structural and tectonic modelling and its application to petroleum geology. Norwegian Petroleum Society (NPF) Special Publication 1, 153-162.

Peters, K.E. 1986: Guidelines for evaluating petroleum source rock using programmed pyrolysis. American Association of Petroleum Geologists Bulletin 70, 318-329.

Petersen, H.I. 1994: Depositional environments of coals and associated siliciclastic sediments in the Lower and Middle Jurassic of Denmark. The Øresund-5, -7, -13, -15 and -18 wells. Danmarks Geologiske Undersøgelse Serie A 33, 55 pp.

Petersen, H.I. \& Nielsen, L.H. 1995: Controls on peat accumulation and depositional environments of a coal-bearing coastal plain succession of a pull-apart basin; a petrographic, geochemical and sedimentological study, Lower Jurassic, Denmark. International Journal of Coal Geology 27, 99-129.

Petersen, H.I. \& Rosenberg, P. 1998: Reflectance retardation (suppression) and source rock properties related to hydrogenenriched vitrinite in Middle Jurassic coals, Danish North Sea. Journal of Petroleum Geology 21, 247-263.

Petersen, H.I., Bojesen-Koefoed, J.A. \& Nytoft, H.P. 1996: Depositional environment and burial history of a Lower Cretaceous carbonaceous claystone, Bornholm, Denmark. Bulletin of the Geological Society of Denmark 43, 133-142.

Petersen, H.I., Nielsen, L.H., Koppelhus, E.B. \& Sørensen, H.S. 2003: Early and Middle Jurassic mires of Bornholm and the Fennoscandian Border Zone: a comparison of depositional environments and vegetation. In: Ineson, J.R. \& Surlyk, F. (eds): The Jurassic of Denmark and Greenland. Geological Survey of Denmark and Greenland Bulletin 1, 631-656 (this volume).

Radke, M., Schaefer, R.G. \& Leythaeuser, D. 1980: Composition of soluble organic matter in coals: relation to rank and liptinite fluorescence. Geochimica et Cosmochimica Acta $\mathbf{4 4}$, $1787-1800$.

Schmidt, B.J. 1985: A coal petrographic source rock evaluation of the Rhaetic - Jurassic - Lower Cretaceous sediments of the Børglum-1 and Uglev-1 wells, Denmark. Bulletin of the Geological Society of Denmark 33, 239-252.

Schmidt, B.J. 1988: A source rock evaluation of the Mesozoic sediments of the well Hyllebjerg-1, Danish Subbasin. Danmarks Geologiske Undersøgelse Serie C 9, 105 pp.

Sorgenfrei, T. \& Buch, A. 1964: Deep tests in Denmark, 1935-1959. Danmarks Geologiske Undersøgelse III. Række 36, 146 pp.
Suggate, R.P. 1998: Relations between depth of burial, vitrinite reflectance and geothermal gradient. Journal of Petroleum Geology 21, 5-32.

Surlyk, F., Arndorff, L., Hamann, N.-E., Hamberg, L., Johannessen, P.N., Koppelhus, E.B., Nielsen, L.H., Noe-Nygaard, N., Pedersen, G.K. \& Petersen, H.I. 1995: High-resolution sequence stratigraphy of a Hettangian-Sinemurian paralic succession, Bornholm, Denmark. Sedimentology 42, 323-354.

Sørensen, K. 1986: Danish Basin subsidence by cold Triassic rifting on a lithospheric cooling background. Nature 319, 660-663.

Taylor, G.H., Teichmüller, M., Davis, A., Diessel, C.F.K., Littke, R. \& Robert, P. 1998: Organic petrology, 704 pp. Berlin-Stuttgart: Gebrüder Borntraeger.

Teichmüller, M. 1979: Die Diagenese der kohligen Substanzen in den Gesteinen des Tertiärs und Mesozoikums des mittleren Oberrhein-Grabens. Fortschritte in der Geologie von Rheinland und Westphalen 27, 19-49.

Thomsen, E. 1980: Rank of coal and dispersed organic matter in Rhaetian - Jurassic - L. Cretaceous deposits from the onshore part of the Danish Subbasin: Interpretation and implications for the maturity of potential hydrocarbon source rocks, 269 pp. Unpublished Ph.D. thesis, University of Aarhus, Århus, Denmark.

Thomsen, E. 1983: A coal petrographical investigation of the well Fars $\varnothing-1$. DGU Internal report (unnumbered), 14 pp. Copenhagen: Geological Survey of Denmark.

Thomsen, E. 1984: A coal petrographical investigation of the well Års-1. DGU confidential report 1, 19 pp. Copenhagen: Geological Survey of Denmark.

Thomsen, E., Lindgreen, H. \& Wrang, P. 1983: Investigation on the source rock potential of Denmark. Geologie en Mijnbouw 62, 221-239.

Thomsen, E., Damtoft, K. \& Andersen, C. 1987: Hydrocarbon plays in Denmark outside the Central Trough. In: Brooks, J. \& Glennie, K.W. (eds): Petroleum geology of North West Europe, 375-388. London: Graham \& Trotman.

Vejbæk, O.V. 1985: Seismic stratigraphy and tectonics of sedimentary basins around Bornholm, southern Baltic. Danmarks Geologiske Undersøgelse Serie A 8, 30 pp.

Vejbæk, O.V. 1989: Effects of asthenospheric heat flow in basin modelling exemplified with the Danish Basin. Earth and Planetary Science Letters 95, 97-114.

Vejbæk, O.V. 1990: The Horn Graben, and its relationship to the Oslo Graben and the Danish Basin. In: Neumann, E.-R. (ed.): Rift zones in the continental crust of Europe - geophysical, geological and geochemical evidence: Oslo - Horn Graben. Tectonophysics 178, 29-49.

Vejbæk, O.V., Stouge, S. \& Poulsen, K.D. 1994: Palaeozoic tectonic and sedimentary evolution and hydrocarbon prospectivity in the Bornholm area. Danmarks Geologiske Undersøgelse Serie A 34, 23 pp.

Ziegler, P.A. 1982: Geological atlas of western and central Europe, 130 pp. The Hague: Elsevier for Shell Internationale Petroleum Maatschappij. 